\title{
Diversidade taxonômica de Apocynaceae na Serra Negra, MG, Brasil
}

\author{
Carolina Nazareth Matozinhos ${ }^{1,3}$ e Tatiana Ungaretti Paleo Konno ${ }^{2}$
}

Recebido: 11.02.2011; aceito: 24.11.2011

\begin{abstract}
Taxonomic diversity of Apocynaceae at Serra Negra, Minas Gerais State, Brazil). This work aims to present a taxonomic treatment for Apocynaceae from the "Serra Negra", Minas Gerais State, Brazil. Serra Negra is located at Mantiqueira Range, between $21^{\circ} 57^{\prime} 22^{\circ} \mathrm{S}$ and $43^{\circ} 50^{\prime} 43^{\circ} 55^{\prime} \mathrm{W}$, and is characterized by a mosaic of forest formations and rocky fields. Apocynaceae is a widespread family, composed by 3,700 species and 255 genera. In Serra Negra Mountains 12 genera and 24 species were identified. Keys for identification of species are presented with taxonomic descriptions, illustrations and ecological comments.
\end{abstract}

Key words: Atlantic Forest, Biodiversity, Gentianales, Mantiqueira Range

RESUMO - (Diversidade taxonômica de Apocynaceae na Serra Negra, MG, Brasil). Este trabalho apresenta o tratamento taxonômico das espécies de Apocynaceae na Serra Negra, Minas Gerais. A Serra Negra está localizada entre as coordenadas $21^{\circ} 57^{\prime} 22^{\circ} \mathrm{S}$ e $43^{\circ} 50^{\prime} 43^{\circ} 55^{\prime} \mathrm{W}$, na Serra da Mantiqueira, e exibe um conjunto de formações vegetacionais com predomínio de Florestas Ombrófilas Densas e Campos Rupestres. A família Apocynaceae é considerada cosmopolita e possui cerca de 255 gêneros e 3.700 espécies. Na Serra Negra ocorrem 12 gêneros e 24 espécies. São apresentadas chaves de identificação para as espécies, descrições morfológicas, ilustrações e comentários sobre distribuição geográfica.

Palavras-chave: Biodiversidade, Floresta Atlântica, Gentianales, Serra da Mantiqueira

\section{Introdução}

Apocynaceae Adans. é uma das famílias mais representativas das Angiospermas, contendo atualmente cerca de 255 gêneros e 3.700 espécies (Judd et al. 2009). Cosmopolita, com o centro de diversidade nos neotrópicos, Apocynaceae apresenta morfologia floral peculiar dentro das Angiospermas, fator investigado tanto do ponto de vista evolutivo, quanto taxonômico (Endress 1994, Wyatt \& Lipow 2007).

No Brasil, a família tem sido amplamente estudada principalmente em tratamentos taxonômicos para floras locais e, mais recentemente, em estudos filogenéticos (Rapini et al. 2006, Simões et al. 2006, Farinaccio 2007). No Estado de Minas Gerais, os estudos acerca da família concentram-se especialmente nos campos rupestres e cerrado, ao longo da Cadeia do
Espinhaço (Rapini et al. 2001, Oliveira \& Pirani 2003) e na porção central do Estado (Fontella-Pereira et al. 1984, 1987, Simões \& Kinoshita 2002). Há, contudo, uma lacuna de conhecimento ao longo da Serra da Mantiqueira Mineira e adjacências, com esparsos trabalhos publicados recentemente (Monguilhott \& Mello-Silva 2008, Matozinhos \& Konno 2008).

A Serra Negra, localizada na Serra da Mantiqueira, exibe uma fitofisionomia complexa, composta por Campos Rupestres e Florestas Ombrófilas, além de áreas ecotonais. É uma área notavelmente diversa (Menini Neto et al. 2009) e conta com o registro, até agora, de pelo menos quatro espécies novas nas famílias Apocynaceae, Lauraceae e Orchidaceae (Batista et al. 2008, Assis \& Mello-Silva 2010, Matozinhos \& Konno 2011)

Este trabalho teve por objetivo investigar a diversidade taxonômica das Apocynaceae na Serra

1. Parte da dissertação de mestrado da primeira autora. Programa de Pós-Graduação em Botânica, Museu Nacional/UFRJ. Quinta da Boa Vista s/no , São Cristóvão, 20940-040 Rio de Janeiro, RJ, Brasil

2. Universidade Federal do Rio de Janeiro, Núcleo em Ecologia e Desenvolvimento Sócio-Ambiental de Macaé, Caixa Postal 119331, 27910-970 Macaé, RJ, Brasil

3. Autor para correspondência: cnmatozinhos@gmail.com 
Negra, fornecendo descrições detalhadas das espécies, chaves de identificação, e pranchas ilustrativas para o reconhecimento e identificação do grupo.

\section{Material e métodos}

A Serra Negra localiza-se ao sul da Zona da Mata Mineira, entre os municípios de Santa Bárbara do Monte Verde, Rio Preto, Lima Duarte e Olaria, na Serra da Mantiqueira Meridional. Tem aproximadamente $15 \mathrm{~km}$ de extensão e está localizada entre as coordenadas $21^{\circ} 57^{\prime} 22^{\circ} \mathrm{S}$ e $43^{\circ} 50^{\prime} 43^{\circ} 55^{\prime} \mathrm{W}$, com altitudes entre 900 e $1.760 \mathrm{~m}$ (IBGE 2006). O clima da região é mesotérmico com verões brandos e uma estação chuvosa ( $\mathrm{Cwb}$ ). A temperatura média anual fica entre 17 e $20^{\circ} \mathrm{C}$, com geadas esporádicas entre maio e agosto. Nas regiões mais elevadas com cota superior a $1.000 \mathrm{~m}$, a temperatura oscila entre 16 e $19^{\circ} \mathrm{C}$, ocorrendo geadas esporádicas e precipitação com média anual de $1.886 \mathrm{~mm}$ e mediana $1.902 \mathrm{~mm}$. A cobertura vegetal é predominantemente composta por Campos Rupestres a partir de 1.000 m e Floresta Ombrófila Densa, que ocupa as regiões altas e úmidas das serras (Menini-Neto et al. 2009, incluindo mapa de localização).

Foram realizadas expedições de coleta em diferentes estações do ano, no período de 2004 a 2009. Os materiais coletados foram incorporados ao acervo dos herbários R e CESJ. A identificação foi realizada por meio de consulta à bibliografia especializada $\mathrm{e}$ por comparação. Para complementação das descrições taxonômicas foram analisadas as coleções dos herbários RB, BHCB, GFJP, HUEFS e R, acrônimos segundo Thiers (2008).

Todos os espécimes foram estudados detalhadamente quanto aos caracteres vegetativos e reprodutivos. Estruturas relevantes para a taxonomia do grupo e de pequenas dimensões, como polinários em Asclepiadoideae, foram medidas e esboçadas com o auxílio de escala acoplada ao microscópico e câmara clara. A partir dos dados obtidos foram elaboradas descrições morfológicas, chaves de identificação, complementadas por dados fenológicos e ecológicos e ilustrações botânicas que auxiliam na identificação.

Para a descrição morfológica a nomenclatura das estruturas seguiu Radford et al. (1974) e Harris \& Harris (2001) e, além de referências específicas para a família. As descrições estão padronizadas dentro de cada subfamília de Apocynaceae, consideradas as particularidades morfológicas de cada grupo.
Os dados referentes à distribuição geográfica das espécies para o Brasil foram obtidos pelo banco de dados SpeciesLink (http://splink.cria.org.br acessado em 10/10/09), além de consultas bibliográficas.

\section{Resultados e Discussão}

$\mathrm{Na}$ Serra Negra, Apocynaceae está representada por 12 gêneros e 24 espécies: Aspidosperma olivaceum Müll.Arg., A. parvifolium A.DC., Condylocarpon isthmicum (Vell.) A.DC., Tabernaemontana catharinensis A.DC. e T. hystrix Steud., pertencentes à subfamília Rauvolfioideae; Forsteronia glabrescens Müll.Arg, F. velloziana (A.DC.) Woodson, Mandevilla atroviolacea (Stadelm.) Woodson, M. funiformis (Vell.) K.Schum., M. pendula (Ule) Woodson, M. sellowii (Müll.Arg) Woodson, M. tenuifolia (J.C.Mikan) Woodson, e Prestonia coalita (Vell.) Woodson, da subfamília Apocynoideae e Asclepias curassavica L., Ditassa aff. bicolor Decne., D. conceptionis Fontella, D. mucronata Mart., D. tomentosa (Decne.) Fontella, Macroditassa mantiqueirae Matozinhos \& T.U.P. Konno, Oxypetalum alpinum (Vell.) Fontella \& E.A. Schwarz var. alpinum, O. banksii Schult. subsp. banksii, O. lanatum Decne ex E.Fourn., Peplonia organensis (E.Fourn.) Fontella \& Rapini e Orthosia scoparia (Nuttal) Liede \& Meve, espécies da subfamília Asclepiadoideae.

\section{Apocynaceae Adans.}

Árvores, arbustos, lianas, trepadeiras ou ervas, latescentes. Folhas simples, pecioladas ou subsésseis, alternas, opostas ou verticiladas, coléteres geralmente presentes. Flores solitárias, em cimeiras ou racemos, hermafroditas, actinomorfas, pentâmeras. Corola gamopétala, rotácea, campanulada, infundibiliforme ou hipocrateriforme, de colorido variado, prefloração sinistrorsa ou dextrorsa, contorta. Corona corolínica ou ginostegial, muitas vezes presente. Estames 5, epipétalos com filetes curtos, livres ou anteras sésseis; anteras introrsas, livres a totalmente adnatos à cabeça do estilete, formando o ginostégio. Grãos de pólen dispersos livremente, em tétrades ou em polínios. Ovário súpero ou semi-ínfero, bicarpelar, geralmente apocárpico, glabro ou piloso; nectários ou discos nectaríferos geralmente presentes. Folículos secos ou carnosos, por vezes moniliformes, cápsulas, drupas ou bagas; sementes nuas, aladas ou comosas, por vezes ariladas. 
Chave de identificação para as espécies de Apocynaceae da Serra Negra

1. Prefloração sinistrorsa; anteras livres da cabeça do estilete; sementes nuas, ariladas ou aladas

2. Lianas ou arbustos escandentes . 4. Condylocarpon isthmicum

2. Árvores ou arvoretas

3. Folhas alternas.; lobos da corola oblíquos, suberetos

4. Ramos jovens pubescentes, de coloração amarelada; folhas de margem lisa, glabras na face abaxial; flores pubérulas

2. Aspidosperma olivaceum

4. Ramos jovens tomentosos, de coloração ferrugínea; folhas de margem crenulada, puberulenta nas nervuras da face abaxial; flores tomentosas 3. Aspidosperma parvifolium

3. Folhas opostas; lobos da corola dolabriformes, patentes

5. Pedicelo com até $0,8 \mathrm{~cm}$ compr., cálice com lacínios obovados, eretos; lobos da corola ca. 0,6 cm larg.; tubo ca. 0,6 cm compr.

24. Tabernaemontana catharinensis

5. Pedicelo superando $0,8 \mathrm{~cm}$ compr.; cálice com lacínios lanceolados, reflexos; lobos

da corola 1-1,2 cm larg.; tubo 1,2-1,4 cm compr.

23. Tabernaemontana hystrix

1. Prefloração dextrorsa; anteras adnatas total ou parcialmente à cabeça do estilete; sementes comosas

6. Flores de corola infundibiliforme ou hipocrateriforme; anteras totalmente inclusas no tubo

7. Flores amarelas, com anel carnoso na fauce 22. Prestonia coalita

7. Flores róseas, atrovioláceas ou lilases, sem anel carnoso na fauce

8. Ervas ou subarbustos; folhas lineares e estreito-elípticas; corola hipocrateriforme

8. Lianas; folhas elípticas a obovadas ou cordiformes; corola infundibiliforme

9. Tubo superior campanulado; lobos patentes

10. Coléteres nodais triangulares, não formando uma bainha; folhas cordiformes; sementes com prolongamento apical 13. Mandevilla funiformis

10. Coléteres nodais formando uma bainha coriácea; folhas elípticas; sementes sem prolongamento apical 15. Mandevilla sellowii

9. Tubo superior tubuloso a tubuloso-campanulado; lobos suberetos a eretos

11. Flores rubras a atrovioláceas 12. Mandevilla atroviolacea

11. Flores brancas a róseas 14. Mandevilla pendula

6. Flores de corola rotácea, campanulada ou urceolada; anteras total ou parcialmente exsertas do tubo

12. Grãos de pólen livres

13. Folhas com domácias; folículos moniliformes, 20-45 cm compr. 9. Forsteronia glabrescens

13. Folhas sem domácias; folículos cilíndricos, $6,3-8 \mathrm{~cm}$ compr. 10. Forsteronia velloziana

12. Grãos de pólen agrupados em polínias

14. Erva ou subarbusto ereto; segmentos da corona providos com um cornículo falcado 1. Asclepias curassavica

14. Lianas, trepadeiras ou subarbustos volúveis; segmentos da corona desprovidos de cornículo 15. Inflorescências subaxilares, alternas

16. Lobos da corola ovados a oblongos, nunca torcidos; cabeça do estilete capitada ou mamilada no ápice

17. Folhas membranáceas; corola subcampanulada, pedicelo 3-8 mm compr.

18. Lobos da corola ca. $3 \times 2 \mathrm{~mm}$, papilosos, ápice ereto 5. Ditassa aff. bicolor

18. Lobos da corola ca. $7 \times 1 \mathrm{~mm}$, pubescentes, ápice reflexo . 8. Ditassa tomentosa

17. Folhas cartáceas a coriáceas; corola rotácea, pedicelo até $3 \mathrm{~mm}$ compr.

19. Corona com segmentos externos mais altos que o ginostégio ...... 7. Ditassa mucronata 19. Corona com segmentos externos mais baixos que o ginostégio

6. Ditassa conceptionis

16. Lobos da corola geralmente lanceolados, torcidos; cabeça do estilete bífida no ápice 20. Inflorescências corimbiformes; segmentos da corona mais baixos que o ginostégio 19. Oxypetalum banksii subsp. banksii 
20. Inflorescências umbeliformes; segmentos da corona mais altos que o ginostégio

21. Lâmina foliar lanceolada a oblanceolada, glabrescente; cabeça do estilete com ramos divergentes 18. Oxypetalum alpinum var. alpinum

21. Lâmina foliar oblonga a oval, lanosa; cabeça do estilete com ramos convergentes 20. Oxypetalum lanatum

15. Inflorescências axilares, opostas, se subaxilares então o pedúnculo inferior a 0,5 mm compr. (inconspícuo).

22. Pedicelo 5-7 mm compr.; corona dupla 11. Macroditassa mantiqueirae

22. Pedicelo menor que $5 \mathrm{~mm}$ compr.; corona simples

23. Corola urceolada, lobos internamente barbelados

23. Corola rotácea, lobos internamente papilosos

21. Peplonia organensis 17. Orthosia scoparia

\section{Asclepias L.}

O gênero possui cerca de 490 espécies de distribuição pantropical (Fontella-Pereira \& Konno 2005). No Brasil ocorrem cerca de seis espécies, preferencialmente em campos rupestres, cerrados e em áreas degradadas de forma subespontânea.

1. Asclepias curassavica L., Sp. Pl. 1: 215. 1753. Figura $1 \mathrm{a}-\mathrm{c}$

Erva ou subarbusto; ramos eretos, puberulentos, esverdeados; coléteres nodais ausentes. Folhas opostas; pecíolo 0,4-1 cm compr., pubescentes; lâmina 4-8 × 0,5-1,8 cm, cartácea, elíptica a lanceolada, ápice acuminado, base aguda, margem levemente revoluta, glabras em ambas as faces; coléteres presentes. Inflorescência subaxilar, umbeliforme; pedúnculo 10-25 mm compr., pubescente; brácteas ca. $2 \mathrm{~mm}$ compr., pubescentes. Flores vermelhas; pedicelo 3-15 mm compr., pubescente; lacínios do cálice 2-3 × 0,3-0,5 mm, lanceolados, externamente pubescentes; coléteres calicinais presentes; corola dextrorsa, rotácea, lobos ca. $8 \times 3 \mathrm{~mm}$, reflexos, oblongos, glabros em ambas as faces; tubo inconspícuo; corona simples; segmentos ca. $3 \times 2 \mathrm{~mm}$, amarelos, cuculados no ápice com cornículo central falcado e inflexo, mais altos que o ginostégio. Ginostégio estipitado; cabeça do estilete 5-lobada; anteras quadradas, asas mais longas que o dorso, apêndice membranáceo orbicular, inflexo sobre o ginostégio. Corpúsculo 0,3-0,5 mm compr., sagitiforme; caudículas ca. 0,3 mm compr., descendentes, planas, inseridas no ápice das polínias; polínias ca. $0,9 \mathrm{~mm}$ compr., ovadas. Fruto não observado.

Material examinado: BRASIL. Minas Gerais: Rio Preto, Serra Negra, próximo à Gruta do Funil, 30-VIII-2008, fl., C.N. Matozinhos et al. 402 (CESJ).

Amplamente distribuída e subespontânea no Brasil. Planta ruderal, encontrada em ambiente antropizado.
Aspidosperma Mart. \& Zucc.

O gênero apresenta 44 espécies com distribuição neotropical, desde o México até a Argentina (exceto no Chile), a maioria ocorrendo no Brasil (Marcondes-Ferreira 2005). Segundo Marcondes-Ferreira \& Kinoshita (1996) pode-se reconhecer dois subgêneros, Coutinia (Vell.) Marcondes-Ferreira e Aspidosperma. Na Serra Negra as espécies encontradas pertencem ao subgênero Aspidosperma, secção Aspidosperma que é caracterizada pelas folhas congestas no ápice, flores com lobos reflexos na antese e frutos biconvexos dolabriformes.

2. Aspidosperma olivaceum Müll.Arg. in Mart., Fl. Bras. 6(1): 57. 1860.

Figura $1 \mathrm{~d}-\mathrm{f}$

Árvore ou arvoreta, 2-5 m alt.; ramos cilíndricos, glabros, por vezes pubescentes-amarelados nos mais jovens, acinzentados, densamente lenticelados, rugosos; coléteres nodais ausentes. Folhas alternas, congestas no ápice dos ramos; pecíolo 0,5-1,3 cm compr., cilíndrico, levemente canaliculado; lâmina 3-6,5 × 1-2,5 cm, cartácea, elíptica a espatulada, ápice arredondado a agudo, base atenuada, margem lisa, face adaxial glabra, opaca, face abaxial glabra, domácias ausentes; coléteres ausentes. Inflorescência axilar, multiflora; pedúnculo ca. $1 \mathrm{~cm}$ compr., tomentoso; brácteas diminutas, inconspícuas. Flores creme ou esverdeadas; pedicelo ca. $0,5 \mathrm{~cm}$ compr., puberulento; lacínios do cálice ca. 2,5 × $1 \mathrm{~mm}$, puberulentos, lanceolados, eretos; coléteres calicinais ausentes; corola sinistrorsa, hipocrateriforme, lobos ca. $3 \times 2 \mathrm{~mm}$, suberetos, oblíquos com ápice arredondado, puberulentos; tubo ca. $0,5 \mathrm{~cm}$ compr., piriforme; anteras livres, inclusas, ca. $1 \times 0,4 \mathrm{~mm}$, oblongas com ápice apiculado; nectários ausentes; ovário ca. $1 \mathrm{~mm}$ compr., piriforme, tomentoso; estilete ca. $2 \mathrm{~mm}$ compr., cabeça do estilete ca. $0,2 \mathrm{~mm}$ compr., 
fusiforme. Folículos 5-7 × 2-3,5 cm, dolabriformes, castanhos, lenticelados, glabros a puberulentos de cor ferrugínea; sementes elípticas, aladas.

Material examinado: BRASIL. Minas Gerais: Rio Preto, Serra Negra. Fazenda da Tiririca, 23-II-2004, fr., F.R. Salimena 1221 (CESJ); Vilarejo do Funil, 21-V-2004, fl., F.R. Salimena et al. 1313 (CESJ); Fazenda da Tiririca, 13-XI-2004, fl., C.N. Matozinhos et al. 131 (CESJ); Fazenda Cachoeira Alta, 15-II-2007, fr., F.R. Salimena et al. 2414 (CESJ); Cachoeira da Água Amarela, 17-III-2007, fr., N.L. Abreu et al. 145 (CESJ); Fazenda Santa Luzia, 31-VI-2007, fr., F.R. Salimena et al. 2467 (CESJ); Trilha para a cachoeira do Marciano, 14-X-2008, fl., fr., C.N. Matozinhos 422 \& N.L. Abreu (CESJ, R); Lima Duarte, Serra Negra, RPPN Serra Negra, 25-X-2008, fl., A.C. Mezzonato et al. 5 (CESJ).

Aspidosperma olivaceum tem registro no Brasil para os Estados da Bahia, Espírito Santo, Goiás, Minas Gerais, Paraná, Rio de Janeiro, Santa Catarina e São Paulo. Encontrada principalmente em matas do Sudeste do Brasil (Marcondes-Ferreira 2005). $\mathrm{Na}$ Serra Negra está presente preferencialmente nos ambientes campestres e arenosos, por vezes em interface com formações florestais.

Esta espécie possui frutos dolabriformes castanhos e flores alvas a esverdeadas. Os ramos jovens com indumento amarelado permitem sua distinção de $A$. parvifolium, cujos ramos jovens apresentam indumento ferrugíneo.

3. Aspidosperma parvifolium A. DC., Prodr. 8: 398. 1844.

Figura 1 g-i

Árvore, ca. $8 \mathrm{~m}$ alt.; ramos cilíndricos, glabros, tomentosos-ferrugíneos nos mais jovens, rubros, lenticelados, rugosos; coléteres nodais ausentes. Folhas alternas, congestas no ápice dos ramos; pecíolo ca. $1 \mathrm{~cm}$ compr., cilíndrico; levemente canaliculado; lâmina 5,5-7,5 × 1,8-2,5 cm, cartácea, oblanceoladas, ápice agudo a acuminado, base atenuada, margem crenulada, face adaxial glabra, brilhante, face abaxial puberulenta, principalmente sobre as nervuras, domácias ausentes; coléteres ausentes. Inflorescência axilar, multiflora; pedúnculo 0,8-2 cm compr., lanoso; brácteas diminutas, inconspícuas. Flores creme ou esverdeadas; pedicelo ca. $0,1 \mathrm{~cm}$ compr., tomentoso; lacínios do cálice 2-2,3 × ca. 0,7 mm, tomentosos, lanceolados, eretos; coléteres calicinais ausentes; corola sinistrorsa, hipocrateriforme, lobos ca. $3 \times 2,2 \mathrm{~mm}$, suberetos, oblíquos com ápice agudo, pubescentes; tubo ca. 0,5 cm compr., piriforme; anteras livres, inclusas, ca. $1 \times 0,4 \mathrm{~mm}$, oblongas com ápice apiculado; nectários ausentes; ovário ca. $1 \mathrm{~mm}$ compr., piriforme, densamente piloso; estilete ca. 2 mm compr.; cabeça do estilete ca. 0,2 $\mathrm{mm}$ compr., cilíndrica. Folículos 4,5-5,5 × 1,9-2,3 cm, dolabriformes, castanhos, lenticelados, tomentosos quando imaturos; sementes elípticas, aladas.

Material examinado: BRASIL. Minas Gerais: Lima Duarte, Serra Negra, RPPN Serra Negra, 10-V-2008, fr., N.L. Abreu \& L. Menini Neto 219 (CESJ); 25-X-2008, fr., J.A. Oliveira et al. 16 (CESJ); 27-X-2008, fl., D. Monteiro 400 (CESJ, R); 31-V-2009, fr., J.H.C. Ribeiro \& F.S. Souza 132 (CESJ).

Ocorre no sudeste do Brasil, preferencialmente ao longo das serras do Mar, da Mantiqueira e dos Órgãos (Marcondes-Ferreira 2005).

Aspidosperma parvifolium foi coletada apenas na vertente norte da Serra Negra. Esta espécie já foi tratada por Marcondes-Ferreira (1988) com uma circunscrição mais ampla, incluindo tanto A. olivaceum quanto A. australe Müll. Arg. Esse complexo de espécies parece hibridizar-se (Duarte 1980), o que dificulta ainda mais a delimitação dos táxons. Como o próprio autor não adotou tal cirscunscrição na Flora de São Paulo (Marcondes-Ferreira 2005), é preferível tratar A. parvifolium e A. olivaceum como táxons independentes.

\section{Condylocarpon Desf.}

Gênero com sete espécies que ocorrem principalmente no Brasil e Guianas, com apenas uma espécie representada na América Central (Kinoshita 2005). Na Serra Negra ocorre apenas C. isthmicum, espécie mais amplamente distribuída do gênero no Sudeste do Brasil.

4. Condylocarpon isthmicum (Vell.) A.DC., Prodr. 8: 381.1844.

Figura 2 a-b

Liana ou arbusto escandente; ramos cilíndricos, glabros a pubescentes, castanhos, lenticelados, esparsamente rugosos; coléteres nodais ausentes. Folhas verticiladas, raramente opostas, distribuídas ao longo dos ramos; pecíolo 0,8-0,1 cm compr., cilíndrico, canaliculado; lâmina (4-)9-10 × 2,5-4,5 cm, membranácea a cartácea, elíptica ou elíptico-obovada, ápice agudo a acuminado, base atenuada, margem lisa, face adaxial glabra, opaca, face abaxial glabra a 


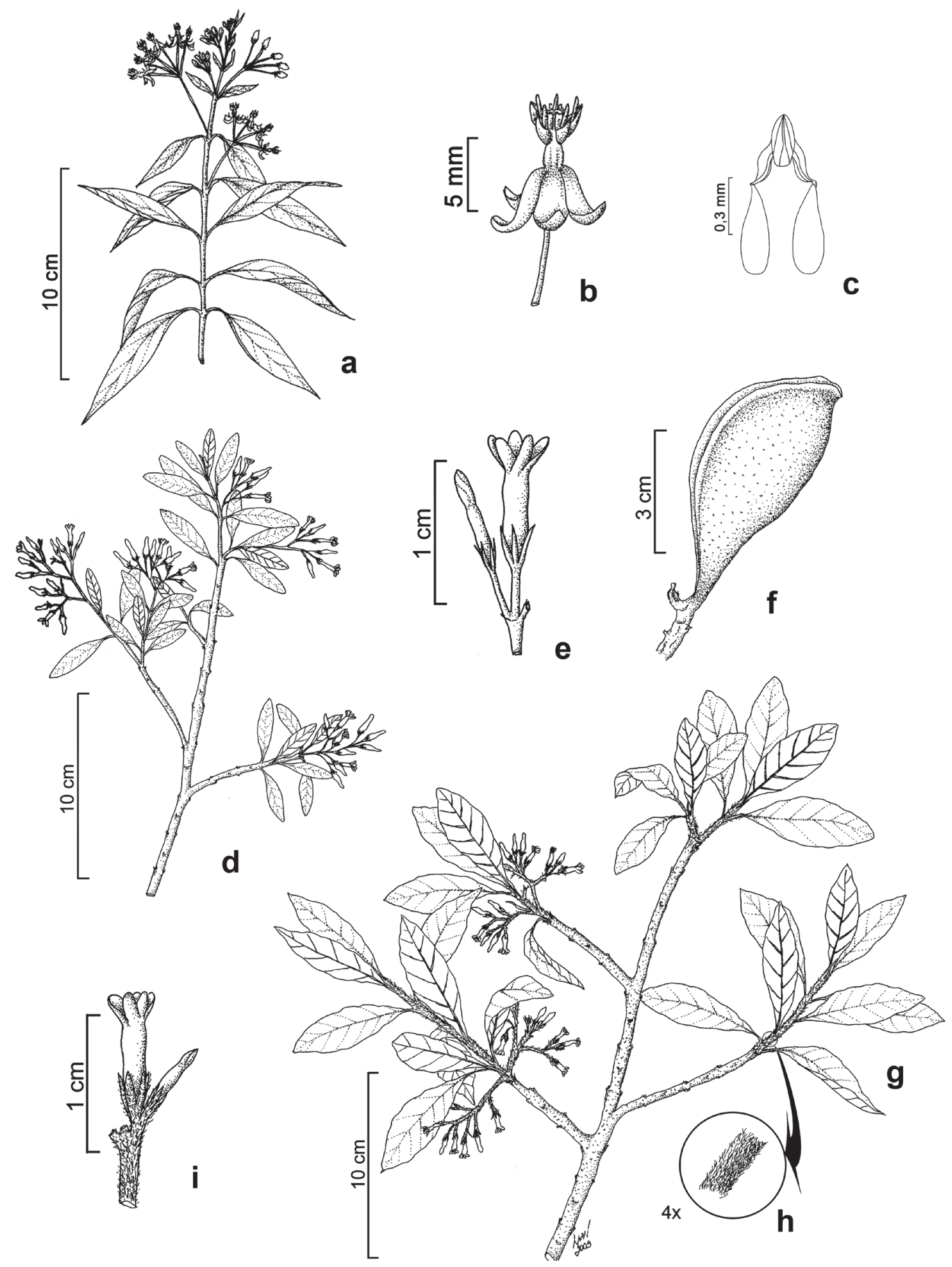

Figura 1. a-c. Asclepias curassavica. a. Ramo florífero. b. Flor. c. Polinário. d-f. Aspidosperma olivaceum. d. Ramo florífero. e. Flor e botão floral. f. Fruto. g-i. Aspidosperma parvifolium. g. Ramo florífero. h. Detalhe do indumento do ramo. i. Flor e botão floral (a-c: Matozinhos et al. 402; d-f: Matozinhos \& Abreu 422; g-i: Monteiro et al. 400).

Figure 1. a-c. Asclepias curassavica. a. Flowering branch. b. Flower. c. Pollinarium. d-f. Aspidosperma olivaceum. d. Flowering branch. e. Flower and floral bud. f. Fruit. g-i. Aspidosperma parvifolium. g. Flowering branch. h. Detail of branch indumentum. i. Flower and floral bud (a-c: Matozinhos et al. 402; d-f: Matozinhos \& Abreu 422; g-i: Monteiro et al. 400). 
pubescente, domácias presentes nas axilas das nervuras secundárias; coléteres ausentes. Inflorescência axilar, multiflora; pedúnculo 2,6-4,5 cm compr., glabro, brácteas ca. $1 \times 0,5 \mathrm{~mm}$, lanceoladas a ovadas. Flores creme; pedicelo 0,3-0,5 cm compr., glabro; lacínios do cálice ca. $1 \times 0,3 \mathrm{~mm}$, glabros, ovados, eretos; coléteres calicinais ausentes; corola sinistrorsa, hipocrateriforme, lobos ca. $4 \times 2 \mathrm{~mm}$, dolabriformes, obovados com ápice longo-caudado, glabros; tubo ca. 0,2 cm compr., obcônico; anteras livres, inclusas, ca. $0,2 \times 0,1 \mathrm{~mm}$, sagitadas com ápice agudo; nectários ausentes; ovário ca. $0,5 \mathrm{~mm}$ compr., piriforme, glabro; estilete subséssil, cabeça do estilete ca. $0,2 \mathrm{~mm}$ compr., globosa. Mericarpos articulados 10-20 cm compr., castanhos ou esverdeados, glabros; sementes ovaladas, não aladas.

Material examinado: BRASIL. MinAs Gerais: Rio Preto, Serra Negra, Fazenda da Tiririca, 22-II-2004, fr., K. Antunes et al. 19 (CESJ); Vilarejo do Funil, 12-IX-2004, fr., C.N. Matozinhos et al. 101 (CESJ); Estrada Rio Preto - Vilarejo do Funil, 17-III-2007, fr., L. Menini Neto et al. 355 (CESJ); Trilha para o Cânion do Funil, 3-II-2009, fr., J.A. Oliveira 25 (CESJ, R). Lima Duarte, Serra Negra, Estrada para Monte Verde de Cima, 15-XI-2008, fl., F.R. Salimena \& P.H. Nobre 2745 (CESJ).

No Brasil ocorre nos Estados da Bahia, Ceará, Espírito Santo, Goiás, Mato Grosso, Mato Grosso do Sul, Minas Gerais, Paraná, Rio de Janeiro, Santa Catarina, São Paulo e no Distrito Federal. Encontrada em matas pluviais, matas inundadas e campos (Kinoshita 2005). Na Serra Negra, C. isthmicum foi observada em locais mais sombreados, interior de mata, próximo a cursos d'água em matas ciliares, ou até em áreas de transição entre campos e bordas de mata.

Espécie facilmente reconhecível pelos frutos moniliformes e flores diminutas com lobos da corola contorcidos. Observa-se uma grande variação de hábitos, podendo ser encontrada como liana ou arbusto escandente.

\section{Ditassa R. Br.}

Ditassa é um gênero Neotropical, composto por cerca de 100 espécies e distribuído por toda a América Latina, exceto Chile. No Brasil estima-se que ocorram cerca de 50 espécies (Konno 2005). Na Serra Negra quatro espécies foram encontradas: Ditassa aff. bicolor, D. conceptionis, D. mucronata e D. tomentosa.

5. Ditassa aff. bicolor Decne., Prodr. 8: 575. 1844. Figura $2 \mathrm{c}-\mathrm{f}$
Liana; ramos volúveis, bilateralmente pubescentes, castanho-esverdeados; coléteres nodais ausentes. Folhas opostas; pecíolo 3-5 mm compr., pubescente; lâmina 1,5-3 × 0,8-1,2 cm, membranácea, oval lanceolada a elíptica, ápice mucronado, base cuneada, margem plana, glabras em ambas as faces; coléteres presentes. Inflorescência subaxilar, umbeliforme; pedúnculo 1-1,5 mm compr., glabro; brácteas diminutas, glabras. Flores creme; pedicelo 4-8 mm compr., glabro; lacínios do cálice ca. $1 \times 0,5 \mathrm{~mm}$, ovais, glabros; coléteres calicinais presentes; corola dextrorsa, subcampanulada, lobos ca. $3 \times 2 \mathrm{~mm}$, patentes, ovais a lanceolados, externamente glabros, internamente papilosos; tubo ca. $0,4 \mathrm{~mm}$ compr.; corona simples; segmentos externos ca. $1,2 \times 0,5 \mathrm{~mm}$, alvacentos, oval-lanceolados com ápice denteado, mais baixos ou da mesma altura que o ginostégio; segmentos internos inconspícuos. Ginostégio séssil; cabeça do estilete com ápice capitado; anteras retangulares, asas mais longas que o dorso, apêndice membranáceo orbicular, inflexo sobre o ginostégio. Corpúsculo ca. $0,23 \times 0,15 \mathrm{~mm}$, elipsóide; caudículas ca. $0,1 \mathrm{~mm}$ compr., horizontais, filiformes, inseridas lateralmente nas polínias; polínias ca. $0,22 \times 0,13 \mathrm{~mm}$, oblongas. Fruto não observado.

Material examinado: BRASIL. Minas Gerais: Rio Preto, Serra Negra, Região do Burro de Ouro, 26-II-2006, fl., P.L. Vianna \& N.F. Mota 1984 (CESJ).

No Brasil ocorre nos Estados de Minas Gerais, Rio de Janeiro e São Paulo, em Floresta Pluvial Atlântica. Segundo Konno (2005), Ditassa bicolor é uma das poucas espécies do gênero que ocorre em florestas pluviais do sudeste brasileiro. Para Minas Gerais, há o registro recente para a localidade do Parque Estadual de Ibitipoca e a coleção-tipo que não possui descrição da localidade.

É reconhecível por possuir folhas glabras, membranáceas e discolores. O espécime coletado na Serra Negra, possui corona simples, porém compartilha as demais características com $D$. bicolor que possui corona dupla na forma típica. Desta forma, optou-se por não identificá-lo até o nível específico, pois são necessárias novas coletas desse material para avaliar a estabilidade dessas características.

6. Ditassa conceptionis Fontella, Dusenia 12(1): 6. 1980.

Figura 2 g-k

Liana ou subarbusto volúvel; ramos volúveis, bilateralmente pubescentes, esverdeados; coléteres nodais ausentes. Folhas opostas, pecíolo 1-3 mm 
compr., glabro a pubescente; lâmina 1-2 × 0,3-0,6 cm, cartácea, estreito elíptica ou obovada, ápice mucronado, base aguda, margem revoluta, glabras em ambas as faces; coléteres presentes. Inflorescência subaxilar, umbeliformes; pedúnculo 2-2,5 mm compr., glabro; brácteas diminutas, glabras. Flores alvas ou amarelas; pedicelo 2-3 mm compr., glabro; lacínios do cálice ca. $1 \times 0,5 \mathrm{~mm}$, ovais, glabros; coléteres calicinais presentes; corola dextrorsa, rotácea, lobos ca. $5 \times 2,5 \mathrm{~mm}$, patentes, ovados, externamente glabros, internamente papilosos; tubo inconspícuo; corona dupla; segmentos externos ca. 1,5 $\times 1 \mathrm{~mm}$, róseo-alvacentos, oval lanceolados, ápice agudo, levemente reflexo, base côncava, mais baixos que o ginostégio; segmentos internos inconspícuos ou pequenas pregas entre as asas da antera. Ginostégio séssil; cabeça do estilete com ápice capitado a mamilado; anteras quadradas, asas mais longas que o dorso, apêndice membranáceo suborbicular, inflexo sobre o ginostégio. Corpúsculo 0,13-0,14 × 0,22-0,24 mm, elipsóide; caudículas $0,7-0,12 \mathrm{~mm}$ compr., horizontais, planas, inseridas lateralmente nas polínias; polínias 0,2-0,26 × 0,1-0,14 mm, oblongas. Folículo 3-3,4 cm compr., fusiforme, glabro; sementes ovadas, coma alvacenta.

Material examinado: BRASIL. Minas Gerais: Rio Preto, Serra Negra, Trilha Ninho da Égua, 22-IV-2005, fl., fr., C.N. Matozinhos et al. 230 (CESJ); 25-IV-2005, fl., C.N. Matozinhos et al. 201 (CESJ); Burro de Ouro, 21-I-2006, fl., fr., T. Konno et al. 865 (CESJ); Atrás da Gruta do Funil, 1-V-2009, fl., C.N. Matozinhos et al. 441 (CESJ, R).

Ocorre no Brasil nos Estados de Minas Gerais, Rio de Janeiro e São Paulo, em campos rupestres e campos de altitude, acima de $1.200 \mathrm{~m}$ de altitude.

Ditassa conceptionis possui flores alvacentas a creme e corona carnosa, além de folhas obovadas e coriáceas, glabras, o que a distingue das demais espécies do gênero que ocorrem na localidade. Em trabalhos recentes foi descrito que esta espécie possui segmentos internos da corona bastante reduzidos, apresentando-se com pregas entra as asas da antera (Konno 2005, Konno \& Pereira 2005). No entanto, os espécimes analisados da Serra Negra não apresentam esse segmento, semelhante ao observado por Monguilhott \& Mello-Silva (2008). É extremamente abundante na Serra Negra, principalmente nos campos e orlas de matas nebulares.

7. Ditassa mucronata Mart., Nov. Gen. Sp. P1. 1: 52. 1824.

Figura 3 a-f
Liana ou subarbusto volúvel; ramos volúveis, tomentosos, castanho-esverdeados; coléteres nodais ausentes. Folhas opostas; pecíolo 1,5-2 mm compr., hirsuto; lâmina 0,8-1,8 × 0,1-0,5 cm, coriácea, lanceolada, estreito elíptica ou elíptica, ápice mucronado, base cuneada, margem revoluta, face adaxial pubescente, face abaxial pilosa na nervura central; coléteres presentes. Inflorescência subaxilar, umbeliforme; pedúnculo ca. 0,5 mm compr., hirsuto; brácteas diminutas, pilosas. Flores alvacentas; pedicelo 2-2,5 mm compr., hirsuto; lacínios do cálice 0,5-0,6 $\times$ ca. $0,3 \mathrm{~mm}$, lanceolados, externamente hirsutos; coléteres calicinais presentes; corola dextrorsa, rotácea, lobos ca. $2 \times 0,5 \mathrm{~mm}$, patentes, ovados, externamente hirsutos, internamente pilosos; tubo inconspícuo; corona dupla; segmentos externos ca. $2 \times 0,4 \mathrm{~mm}$, alvacentos, oblongos, ápice tridentado com o mediano longo caudado, mais altos que o ginostégio; segmentos internos 0,5-1,1 × 0,2 mm, filiformes, mais altos que o ginostégio. Ginostégio séssil; cabeça do estilete com ápice mamilado; anteras retangulares, asas mais longas que o dorso, apêndice membranáceo suborbicular, inflexo sobre o ginostégio. Corpúsculo 0,10-0,13 × 0,05-0,06 mm, elipsóide; caudículas 0,05-0,08 mm compr., horizontais, cilíndricas, sinuosas, inseridas subapicalmente nas polínias; polínias $0,17-0,22 \times 0,05 \mathrm{~mm}$, oblongas. Folículo 1-2 cm compr., fusiforme, hirsuto, sementes ovadas, coma alvacenta.

Material examinado: BRASIL. Minas Gerais: Rio Preto, Serra Negra, Fazenda da Tiririca, 22-II-2004, fl., L.C.S. Assis et al. 982 (CESJ); Trilha para o Ninho da Égua, 22-IV-2005, fr., C.N. Matozinhos et al. 232 (CESJ). Lima Duarte, Serra Negra, Fazenda Serra Negra, Cachoeira da Borboleta Azul, 1-III-2008, fl., F.R. Salimena et al. 2654 (CESJ); 4-IV-2009, fl., J. Miloski et al. 31 (CESJ,R).

Ocorre no Brasil nos Estados da Bahia, Espírito Santo, Minas Gerais, Paraná e Rio de Janeiro em Floresta Pluvial Atlântica, campos de altitude e campos rupestres. Encontrada principalmente nos campos rupestres da Serra Negra nas diversas cotas de altitude.

Forma grandes populações, com ramos eretos, muitas flores e folhas diminutas, coriáceas.

8. Ditassa tomentosa (Decne.) Fontella, Bol. Mus. Bot. Mun. Curitiba 39: 1. 1979. Figura 3 g-k

Liana; ramos volúveis, tomentosos a velutinos, esverdeados; coléteres nodais ausentes. Folhas 


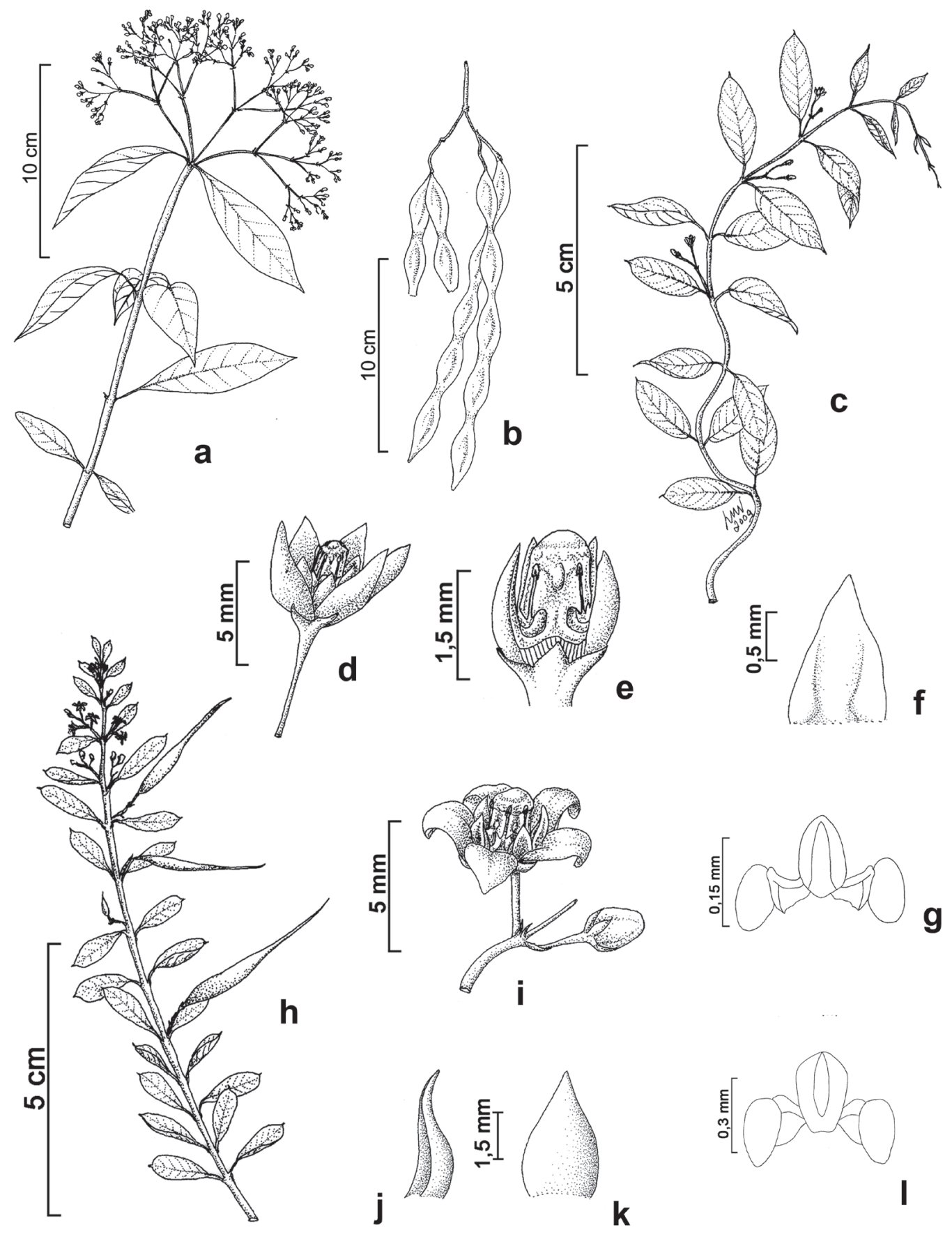

Figura 2. a-b. Condylocarpon isthmicum. a. Ramo florífero. b. Fruto. c-g. Ditassa aff. bicolor. c. Ramo florífero. d. Flor. e. Ginostégio. f. Segmento externo da corona em vista ventral. g. Polinário. h-l. Ditassa conceptionis. h. Ramo com flores e frutos. i. Flor e botão floral. j. Segmentos externos da corona em vista lateral. k. Segmentos externos da corona em vista dorsal. 1. Polinário (a, c: Salimena \& Nobre 2745; b: Matozinhos et al. 101; d-g: Viana et al. 1984; h-1: Matozinhos et al. 230).

Figure 2. a-b. Condylocarpon isthmicum. a. Flowering branch. b. Fruit. c-g. Ditassa aff. bicolor. c. Flowering branch. d. Flower. e. Gynostegium. f. Outer segment of the corona in ventral view. g. Pollinarium. h-1. Ditassa conceptionis. h. Branch with flowers and fruits. i. Flower and floral bud. j. Outer segment of the corona in lateral view. k. Outer segment of the corona in dorsal view. 1. Pollinarium (a, c: Salimena \& Nobre 2745; b: Matozinhos et al. 101; d-g: Viana et al. 1984; h-1: Matozinhos et al. 230). 
opostas; pecíolo 3-5 mm compr., tomentoso; lâmina 2,7-5 × 1-1,8 cm, membranácea, obovada a elíptica, ápice mucronado, base aguda, margem revoluta, tomentosas em ambas as faces; coléteres presentes. Inflorescência subaxilar, umbeliforme; pedúnculo 1,5-2 mm compr., tomentoso; brácteas diminutas, pilosas. Flores alvacentas a esverdeadas; pedicelo 3-5 mm compr., tomentoso; lacínios do cálice 3-4 $\times$ ca. $1 \mathrm{~mm}$, oval-lanceolados, externamente hirsutos; coléteres calicinais ausentes; corola dextrorsa, campanulada, lobos ca. $7 \times 1 \mathrm{~mm}$, eretos, reflexos no ápice, lanceolados a estreito-ovais, externamente glabros, internamente pubescentes; tubo ca. $3 \mathrm{~mm}$ compr.; corona dupla; segmentos externos ca. $1 \times 0,5 \mathrm{~mm}$, alvacentos, oval-triangulares, mais baixos que o ginostégio; segmentos internos inconspícuos. Ginostégio subséssil; cabeça do estilete com ápice capitado; anteras retangulares, asas mais longas que o dorso, apêndice membranáceo triangular, ereto. Corpúsculo ca. 0,2 × 0,09-0,1 mm, oblongo; caudículas 0,06-0,08 mm compr., horizontais, planas, inseridas lateralmente nas polínias; polínias $0,19-0,21 \times 0,09-0,1 \mathrm{~mm}$, ovóides. Fruto não observado.

Material examinado: BRASIL. Minas Gerais: Rio Preto, Serra Negra, Próximo a Gruta do Funil, 2008, fl., C.N. Matozinhos et al. 328 (CESJ, R); 3-II-2009, bf., N.L. Abreu et al. 310 (CESJ); 1-V-2009, fl., C.N. Matozinhos et al. 442 (CESJ).

No Brasil ocorre no Distrito Federal e nos Estados do Espírito Santo, Mato Grosso, Minas Gerais, Paraná, Rio de Janeiro e São Paulo. Habita preferencialmente áreas de Cerrado ou Floresta Pluvial Atlântica. Ditassa tomentosa é geralmente encontrada em regiões de ecótono, mais sombreadas.

Possui folhas e flores maiores que as demais espécies de Ditassa que ocorrem na Serra Negra, além de possuírem indumento tomentoso a velutino em todas as partes da planta.

\section{Forsteronia G. Mey.}

O gênero possui 46 espécies de distribuição neotropical. Na Serra Negra está representado por duas espécies: Forsteronia glabrescens e F. velloziana.

9. Forsteronia glabrescens Müll. Arg. in Mart., Fl. Bras. 6(1): 102. 1860.

Figura 4 a

Liana lenhosa; ramos cilíndricos, glabros, castanhos, rugosos; coléteres nodais ausentes. Folhas opos- tas; pecíolo 0,5-0,8 cm compr., cilíndrico, levemente canaliculado; lâmina 4-9 × 2,2-3,6 cm, cartácea a subcoriácea, elíptica a ovado-elíptica, ápice acuminado a cuspidado, base atenuada, margem lisa, face adaxial glabra, brilhante, face abaxial esparsamente pubescente; domácias em forma de criptas nas axilas das nervuras secundárias; coléteres presentes. Inflorescência terminal, multiflora; pedúnculo 2,2-3,2 cm compr., glabrescente; brácteas ca. $1 \mathrm{~mm}$ compr., ovadas. Flores alvas; pedicelo ca. 0,3 cm compr., glabro; lacínios do cálice 1-2 mm compr., glabros, ovados; suberetos; coléteres calicinais presentes; corola dextrorsa, rotácea, lobos $4-5 \times$ ca. $1 \mathrm{~mm}$, patentes, oblongos com ápice agudo, glabrescentes; tubo único ca. $4 \mathrm{~mm}$ compr.; anteras parcialmente adnatas à cabeça do estilete, parcialmente exsertas, 2-3 mm compr., oblongas com ápice obtuso; nectários 5 , livres, ovados; ovário ca. 1,5 mm compr., ovóide, piloso somente no ápice; estilete inconspícuo, cabeça do estilete ca. 1,3 mm compr., cônica, ápice fusiforme (E. Pereira \& G. Hatschbach 10521). Folículos 20-45 cm compr., moniliformes, castanhos, glabros; sementes não vistas.

Material examinado: BRASIL. MinAs Gerais: Lima Duarte, Serra Negra, RPPN Serra Negra, 20-IV-2009, fr., L. Menini Neto et al. 675 (CESJ, R).

Material adicional examinado: BRASIL. MinAs GeraIs: Toledo Sarandi: 15-XI-1963, fl., E. Pereira \& G. Hatschbach 10521 (RB).

No Brasil foi registrada nos Estados de Minas Gerais, Mato Grosso, Mato Grosso do Sul, Paraná, Rio de Janeiro, Rio Grande do Sul e São Paulo, em formações de mata e cerrado. Forsteronia glabrescens foi coleta em borda de mata na vertente norte da Serra Negra, local ainda pouco explorado pelo projeto.

Esta espécie diferencia-se das demais espécies do gênero ocorrentes no Brasil pelas folhas pequenas e coriáceas (Koch \& Kinoshita 2005).

10. Forsteronia velloziana (A. DC.) Woodson, Ann. Missouri Bot. Gard. 21: 622. 1934. Figura 4 b-c

Liana lenhosa; ramos cilíndricos, glabros a tomentoso-ferrugíneos nos ramos mais jovens, acinzentados, rugosos; coléteres nodais ausentes. Folhas opostas; pecíolo ca. $2 \mathrm{~mm}$ compr., cilíndrico; levemente canaliculado; lâmina 3,5-6,5 × 1,7-2,5 cm, membranácea a cartácea, oblonga a obovada, raro elíptica ápice retuso a acuminado, base retusa, mar- 


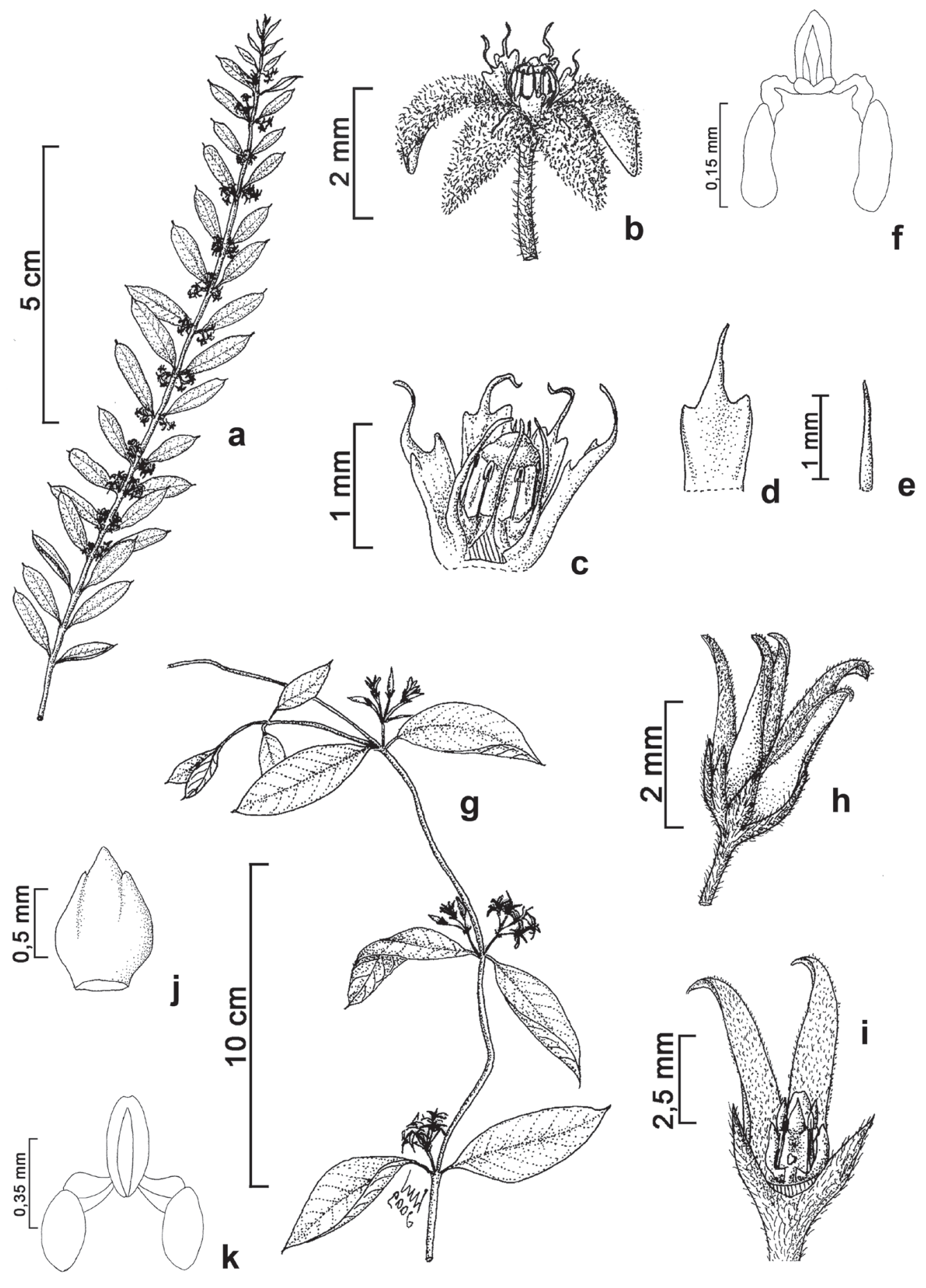

Figura 3. a-f. Ditassa mucronata. a. Ramo florífero. b. Flor. c. Detalhe do ginostégio evidenciando os segmentos externos e internos da corona. d. Segmento externo da corona em vista ventral. e. Segmento interno da corona. f. Polinário. g-k. Ditassa tomentosa. g. Ramo florífero h. Flor. i. Flor, três pétalas retiradas evidenciando o ginostégio. j. Segmento externo da corona em vista dorsal. k. Polinário (a-f: Salimena et al. 2654; g-k: Matozinhos et al. 442).

Figure 3. a-f. Ditassa mucronata. a. Flowering branch. b. Flower. c. Gynostegium showing the corona segments. d. Outer corona segment in ventral view. e. Inner corona segment. f. Pollinarium. g-k. Ditassa tomentosa. g. Flowering branch. h. Flower. i. Gynostegium. j. Outer corona segment in dorsal view. k. Pollinarium (a-f: Salimena et al. 2654; g-k: Matozinhos et al. 442). 
gem ciliada, face adaxial glabra, opaca, face abaxial pubescente a tomentosa; domácias ausentes; coléteres presentes. Inflorescência terminal, multiflora; pedúnculo ca. $0,5 \mathrm{~cm}$ compr., tomentoso; brácteas 2-4 mm compr., lineares a lanceoladas. Flores alvas; pedicelo ca. 0,15 cm compr., tomentoso; lacínios do cálice ca. 2,1 mm compr., tomentuloso-ferrugíneos, ovados, suberetos; coléteres calicinais ausentes; corola dextrorsa, rotácea, lobos 3-3,2 × ca. 1,2 mm, patentes, oblongos com ápice agudo, puberulentos; tubo único ca. $0,1 \mathrm{~cm}$ compr.; anteras parcialmente adnatas à cabeça do estilete, parcialmente exsertas, ca. $2 \mathrm{~mm}$ compr., oblongas com ápice apiculado; nectários 5, livres, triangulares; ovário ca. 0,5 mm compr., ovóide, densamente piloso; estilete ca. $1 \mathrm{~mm}$ compr., cabeça do estilete ca. 1,3 mm compr., cônica, ápice fusiforme. Folículos 6,3-8 cm compr., cilíndricos, ferrugíneos, tomentosos; sementes fusiformes, sem prolongamento apical, coma amarelada.

Material examinado: BRASIL. Minas Gerais: Rio Preto, Serra Negra, Fazenda da Tiririca, 13-XI-2004, fl., C.N. Matozinhos et al. 134 (CESJ, R).

Material adicional examinado: BRASIL. MINAS Gerais: Lima Duarte, Parque Estadual do Ibitipoca: Trilha entre a Ponte de Pedra e Lago dos Espelhos, 13-VII-2005, fr., L. Monguilhott et al. 124 (SPF, CESJ).

No Brasil é encontrada nos Estados do Espírito Santo, Minas Gerais, Paraná, Rio de Janeiro, Santa Catarina e São Paulo. Habita preferencialmente áreas de cerrado aberto e bordas de mata. Ocorre na Serra Negra em áreas de campos arenosos, mais secos, em transição com florestas estacionais.

Forsteronia velloziana é uma liana vigorosa, facilmente identificada pela pilosidade ferrugínea e inflorescência glomeruliforme.

\section{Macroditassa Malme}

O gênero é exclusivo da América do Sul, sendo encontrado na Guiana, Venezuela, Peru, Bolívia e Brasil. Possui 14 táxons, sendo 11 encontrados exclusivamente no Brasil (Fontella-Pereira \& Ferreira 2005). $\mathrm{Na}$ Serra Negra foi descrita uma nova espécie para o gênero, M. mantiqueirae (Matozinhos \& Konno 2011).

11. Macroditassa mantiqueirae Matozinhos \&

T.U.P.Konno, Syst. Bot. 36(1): 137. 2011.

Figura 4 d-f

Liana; ramos volúveis, glabros, esverdeados; coléteres nodais presentes. Folhas opostas; pecíolo 5-9 mm compr., glabro, lâmina 4,3-6,8 × 1-1,5 cm, subcoriácea, elíptica a lanceolada, ápice acuminado-mucronado, base atenuada a obtusa, margem plana, glabras em ambas as faces; coléteres presentes. Inflorescência axilar, umbeliforme; pedúnculo 1,5-2 $\mathrm{mm}$ compr., glabro; brácteas diminutas, ciliadas nas margens. Flores alvas a rosadas; pedicelo 5-7 mm compr., glabro; lacínios do cálice ca. $1,5 \times 0,5 \mathrm{~mm}$, oval-lanceolados, glabros; coléteres calicinais presentes; corola dextrorsa, campanulada, abaxialmente glabra e adaxialmente papilosa, lobos ca. 3,4 × 1,5 mm, suberetos, reflexos no ápice, ovados, externamente glabros, internamente papilosos; tubo inconspícuo; corona dupla; segmentos externos ca. 2,3 × 1,4 mm, alvacentos, lanceolados, fortemente cuculados na base, mais altos que o ginostégio; segmentos internos ca. $0,5 \times 1 \mathrm{~mm}$, fortemente cuculados abaxialmente, ápice inflexo, mais baixos que o ginostégio. Ginostégio séssil; cabeça do estilete com ápice capitado; anteras quadrangulares, asas mais longas que o dorso, apêndice membranáceo suborbicular, inflexo sobre o ginostégio. Corpúsculo ca. 0,18 × 0,11-0,13 mm, oblongo; caudículas 0,06-0,09 mm compr., ascendentes, planas, inseridas lateralmente nas polínias; polínias ca. $0,40 \times 0,09-0,13 \mathrm{~mm}$, oblongas. Fruto não observado.

Material examinado: BRASIL. Minas Gerais: Rio Preto, Serra Negra, Trilha para a Cachoeira do Ninho da Égua, 3-VI-2006, fl., T.U.P. Konno et al. 868 (holótipo CESJ).

Até o momento conhecida somente pelo material-tipo, coletado no Estado de Minas Gerais. Na Serra Negra foi encontrada em área de Floresta Ombrófila, ecotóno com campos, acima dos $1.300 \mathrm{~m}$ de altitude.

Esta espécie é relacionada a Macroditassa lagoensis var. cucullata (E.Fourn.) Fontella \& M.V.Ferreira e Macroditassa marianae Fontella \& M.V.Ferreira, das quais difere pela corola internamente papilosa em toda sua extensão e pelos segmentos da corona internos cuculados dorsalmente e inflexos no ápice.

\section{Mandevilla Lindl.}

Gênero neotropical com cerca de 150 espécies, distribuindo-se do México até a Argentina. Está subdividido em dois subgêneros: Mandevilla e Exothostemon (G. Don) Woodson. No Brasil há cerca de 40 espécies (Sales \& Kinoshita 2005). Na Serra Negra encontramos cinco espécies, todas pertencentes ao subgênero Mandevilla. 

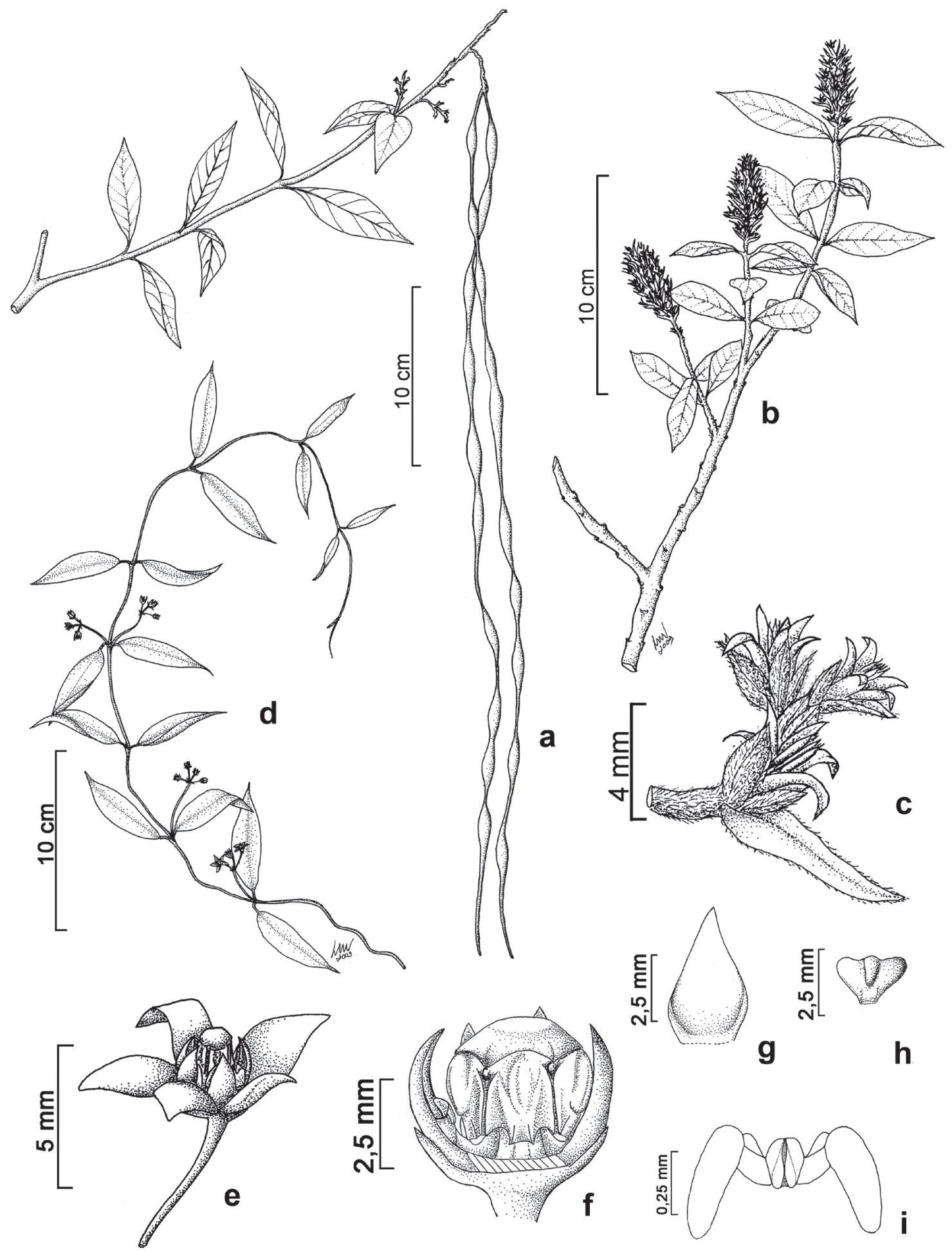

Figura 4. a. Forsteronia glabrescens. a. Ramo com frutos. b-c. Forsteronia velloziana. b. Ramo florífero. c. Detalhe das flores e brácteas florais. d-f. Macroditassa mantiqueirae. d. Ramo florífero. e. Flor. f. Ginostégio. g. Segmento externo da corona em vista ventral. h. Segmento interno da corona em vista ventral. i. Polinário (a: Menini Neto et al. 675; b,c: Matozinhos et al. 164; d-e: Konno et al. 868).

Figure 4. a. Forsteronia glabrescens. a. Branch with fruits. b-c. Forsteronia velloziana. b. Flowering branch. c. Inflorescence fragment showing flowers and floral bracts. d-f. Macroditassa mantiqueirae. d. Flowering branch. e. Flower. f. Gynostegium. g. Outer corona segment in ventral view. h. Inner corona segment in ventral view. i. Pollinarium (a: Menini Neto et al. 675; b,c: Matozinhos et al. 164; d-f: Konno et al. 868). 
12. Mandevilla atroviolacea (Stadelm.) Woodson, Ann. Missouri Bot. Gard 20 (4): 724. 1933.

Figura 5 a-d

Liana lenhosa; ramos cilíndricos, glabros, rubros, lisos; coléteres nodais formando uma bainha coriácea. Folhas opostas; pecíolo 0,8-1,5 cm compr., cilíndrico, canaliculado; lâmina 2-4 × 1,9-2,5 cm, coriácea, elíptico-obovada, ápice longo-caudado, base atenuada, margem revoluta, face adaxial glabra, brilhante, face abaxial glabra; domácias ausentes; coléteres presentes. Inflorescência axilar, 3-4 flora; pedúnculo 3,1-5,4 cm compr., glabro; brácteas inconspícuas. Flores vináceas a atrovioláceas, base inferior do tubo amarela; pedicelo 0,7-1,5 cm compr., glabro; lacínios do cálice ca. $5 \mathrm{~mm}$ compr., glabros, triangulares, eretos; coléteres calicinais presentes; corola dextrorsa, infundibiliforme, lobos 1,5-2 cm compr., suberetos, oblíquos-obovados com ápice truncado, glabros; tubo superior ca. $2 \mathrm{~cm}$ compr., tubuloso, tubo inferior 2-2,5 cm compr., cilíndrico; anteras parcialmente adnatas à cabeça do estilete, inclusas, ca. $8 \mathrm{~mm}$ compr., lanceoladas, com ápice apiculado; nectários 2, livres, oblongos; ovário ca. $4 \mathrm{~mm}$ compr., ovóide, glabro; estilete ca. $24 \mathrm{~mm}$ compr., cabeça do estilete ca. $2 \mathrm{~mm}$ compr., cônica, ápice apiculado. Folículos ca. $16 \mathrm{~cm}$ compr., cilíndricos, castanhos, glabros; sementes não vistas.

Material examinado: BRASIL. Minas Gerais: Rio Preto, Serra Negra, Trilha para o Ninho da Égua, 9-XI-2005, fl., C.N. Matozinhos et al. 252 (CESJ); 27-I-2007, fl., fr., L. Menini Neto et al. 274 (CESJ); Subida para o Burro de Ouro, 10-XII-2008, fl., fr., C.N. Matozinhos 438 \& N.L. Abreu (CESJ, R).

Ocorre no Brasil nos Estados do Espírito Santo, Minas Gerais, Paraná, Rio de Janeiro, Rio Grande do Sul, Santa Catarina e São Paulo, principalmente em formações florestais (Sales 1993). Foi coletada, diferentemente do esperado, nos campos da Serra Negra, a partir de $1.300 \mathrm{~m}$ de altitude.

Mandevilla atroviolacea é uma espécie de liana bem vigorosa, com flores vistosas rubras, de fauce amarela; essas são boas características para distingui-la das demais espécies do gênero na área de estudo. Segundo Sales (1993) esta espécie mostra afinidades com $M$. sellowii e $M$. crassinoda (Gardner) Woodson. Porém, difere da primeira por esta apresentar tubo superior campanulado e os lobos amplamente recurvados, e da segunda pelos ramos nodulosos e folhas lanceoladas.
13. Mandevilla funiformis (Vell.) K.Schum., Nat.

Pflanzenfam. 4(2): 171. 1895.

Figura 5 e-g

Liana sublenhosa; ramos cilíndricos, glabros, castanhos na porção mais basal, lisos; coléteres nodais triangulares, diminutos. Folhas opostas; pecíolo 0,9-1,3 cm compr., cilíndrico, canaliculado; lâmina 3,4-5,5 × 1,2-2,3 cm, membranácea a cartácea, elíptica a ovada ou oblonga, ápice longo-acuminado, base arredondada a subcordada, margem lisa, face adaxial glabra, opaca, face abaxial glabra; domácias ausentes; coléteres presentes. Inflorescência axilar, multiflora; pedúnculo 2,5-5 cm compr., anguloso; brácteas inconspícuas. Flores amarelas com fauce avermelhada; pedicelo 1,4-2 cm, glabro; lacínios do cálice ca. $1 \mathrm{~mm}$ compr., glabros, triangulares, eretos; coléteres calicinais presentes, corola dextrorsa, infundibiliforme, lobos 2-3 $\times$ ca. $2,4 \mathrm{~cm}$, recurvados, obovados; tubo superior ca. $2 \mathrm{~cm}$ compr., campanulado; tubo inferior ca. 1,8 cm compr., cilíndrico; anteras parcialmente adnatas à cabeça do estilete, inclusas, ca. $7 \mathrm{~mm}$ compr., estreito-lanceoladas, com ápice apiculado; nectários 5, unidos entre si, lobados; ovário ca. $2 \mathrm{~mm}$ compr., oblongo; glabro; estilete. ca. $14 \mathrm{~mm}$ compr., cabeça do estilete ca. $2 \mathrm{~mm}$ compr., cônica, ápice apiculado (C. Carcerelli 23). Folículos 18-23 cm compr., cilíndricos, castanhos, glabros; sementes lineares, com um prolongamento apical, coma amarelada.

Material examinado: BRASIL. Minas Gerais: Rio Preto, Serra Negra, Trilha atrás da Gruta do Funil, 3-II-2009, fr., N.L. Abreu et al. 308 (CESJ, R).

Material adicional examinado: BRASIL. RIo DE JANEIRo: Baixada Fluminense, Cidade das Meninas, 8-VII-1942, fl., C. Carcerelli 23 (RB).

Ocorre no Brasil nos Estados da Bahia, Espírito Santo, Minas Gerais, Paraná, Rio de Janeiro, Santa Catarina e São Paulo. É encontrada principalmente em restingas, matas de restinga, e bordas da Floresta Atlântica, como na região de Macaé de Cima (Sales 1993).

Esta espécie foi coletada apenas com frutos, fator que tornaria imprecisa a identificação específica, uma vez que em Mandevilla os caracteres mais diagnósticos são as corolas, suas formas e cores. No entanto, com base em Sales (1993), encontrou-se compatibilidade do material Abreu et al. 308 com M. funiformis, especialmente por compartilharem caracteres diagnósticos para a espécie como folhas glabras de lâmina subcordada e, sementes com um prolongamento apical associadas a coma amarela. 


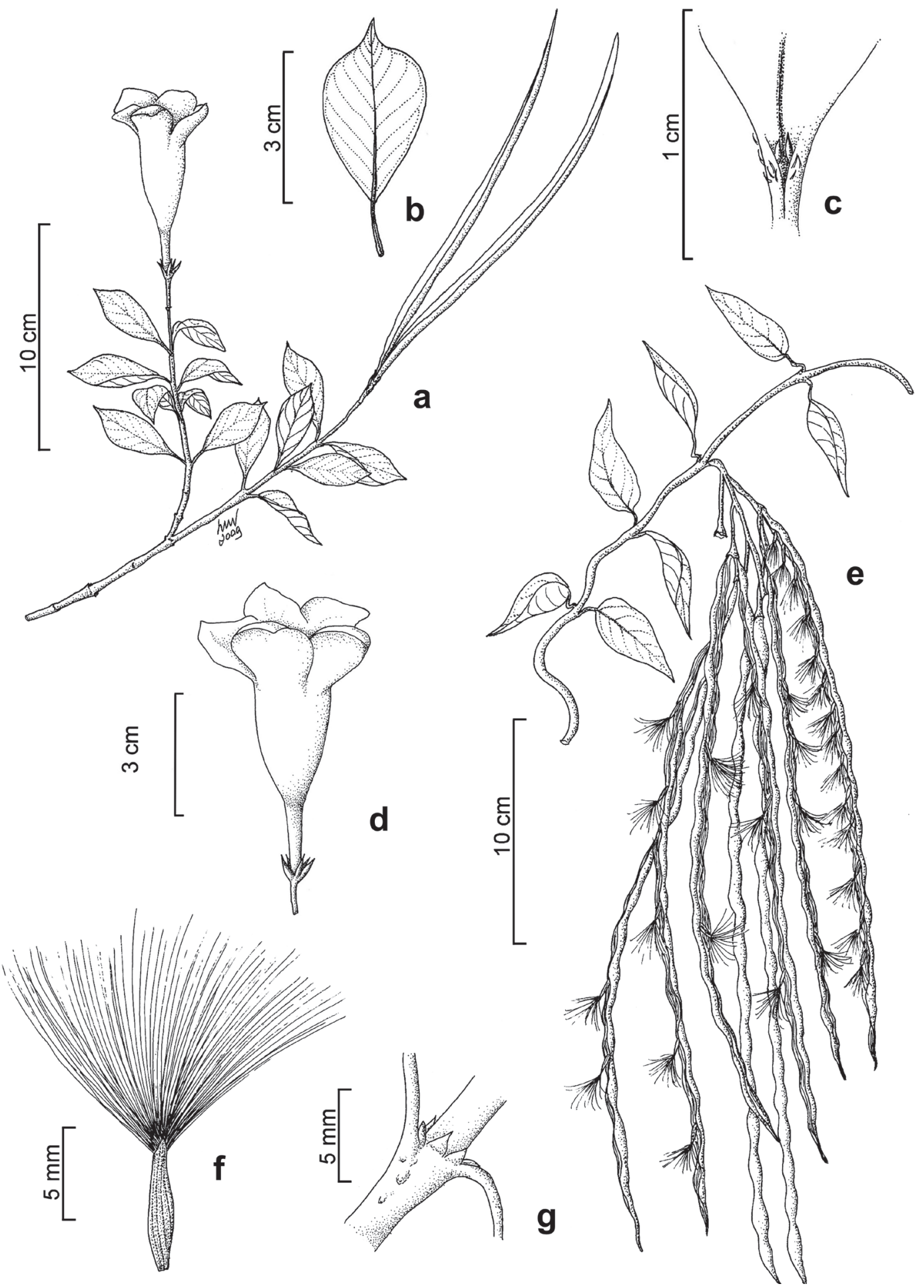

Figura 5. a-d. Mandevilla atroviolacea. a. Ramo com flores e fruto. b. Detalhe da folha. c. Detalhe dos coléteres foliares. d. Flor. e-g. Mandevilla funiformis. e. Ramo com frutos e sementes. f. Semente. g. Detalhe dos coléteres nodais triangulares (a-d: Matozinhos \& Abreu 438; e-g: Abreu et al. 308).

Figure 5. a-d. Mandevilla atroviolacea. a. Branch with flowers and fruits. b. Leaf. c. Leaf base showing foliar colleters. d. Flower. e-g. Mandevilla funiformis. e. Branch with fruits. f. Seed. g. Triangular colleters in stem nodes (a-d: Matozinhos \& Abreu 438; e-g: Abreu et al. 308). 
14. Mandevilla pendula (U1e) Woodson, Ann. Missouri Bot. Gard. 20: 725. 1933.

Figura 6 a-c

Liana lenhosa; ramos cilíndricos, pubérulos, rubros, lisos; coléteres nodais ausentes. Folhas opostas; pecíolo 0,5-0,8 cm compr., cilíndrico, canaliculado; lâmina 2,8-4,4 × 1,1-1,8 cm, coriácea, elíptica a ligeiramente obovada, ápice acuminado, base atenuada, margem levemente revoluta face adaxial glabra, opaca, face abaxial glabra; domácias ausentes; coléteres ausentes. Inflorescência axilar, 8-14 flores; pedúnculo 1-2,3 cm compr., glabro, brácteas diminutas, lanceoladas, Flores externamente róseas, alvacentas na fauce; pedicelo 0,5-1 cm compr., glabro; lacínios do cálice ca. $9 \mathrm{~mm}$ compr., glabros, lanceolados a lineares, eretos, coléteres calicinais presentes; corola dextrorsa, infundibiliforme, lobos ca. $2 \times 1 \mathrm{~cm}$, eretos, ovais a estreito-ovais com ápice agudo, glabros; tubo superior ca. 3,5 compr., tubuloso-campanulado, tubo inferior 1-1,5 cm compr., cilíndrico; anteras parcialmente adnatas à cabeça do estilete, inclusas, ca. $6 \mathrm{~mm}$ compr., estreito lanceoladas com ápice apiculado; nectários 2, livres, oblongos; ovário ca. $1 \mathrm{~mm}$ compr., ovóide, glabro; estilete ca. $11 \mathrm{~mm}$ compr., cabeça do estilete ca. 1,5 mm compr., cônica, ápice apiculado bilobado. Folículos 7-12 cm compr., cilíndricos, castanhos, glabros; sementes não vistas.

Material examinado: BRASIL. Minas Gerais: Rio Preto, Serra Negra, Trilha para o Ninho da égua, 9-XI2005, fl., C.N. Matozinhos et al. 238 (CESJ); Burro de Ouro, 1-IV-2008, fr., C.N. Matozinhos 343 \& N.L. Abreu (CESJ); Trilha para a cachoeira do Marciano, 14-X-2008, fl., C.N. Matozinhos 417 \& N.L. Abreu (CESJ, R); Trilha do Ninho da Égua, 10-XII-2008, fr., C.N. Matozinhos 433 \& N.L. Abreu (CESJ).

Ocorre no Brasil nos Estados de Minas Gerais, Rio de Janeiro e São Paulo, em borda de mata e locais sombreados em altitudes que variam de 1.000 a $2.000 \mathrm{~m}$. Encontrada apenas em duas localidades da Serra Negra, acima de $1.200 \mathrm{~m}$ em campo rupestre. Sales (1993) afirmou que sua distribuição está restrita ao Estado do Rio de Janeiro. No entanto, coletas recentes têm ampliado essa distribuição geográfica, para os Estados de Minas Gerais e São Paulo.

Mandevilla pendula é facilmente reconhecida pelas flores róseas com lobos eretos e alvos. As inflorescências são congestas e eretas quando em hábito volúvel.
15. Mandevilla sellowii (Müll.Arg.) Woodson, Ann Missouri Bot. Gard. 20: 719. 1933.

Figura 6 i-1

Liana lenhosa; ramos cilíndricos, glabros, acinzentados, lisos; coléteres nodais formando uma bainha coriácea. Folhas opostas; pecíolo 1-2,5 cm compr., cilíndrico, canaliculado; lâmina 3,8-6 × 1,6-2,8 cm, coriácea, elíptica, ápice acuminado a longo-caudado, base atenuada, margem levemente revoluta face adaxial glabra, brilhante, face abaxial glabra; domácias ausentes; coléteres presentes. Inflorescência axilar, 2-5-flora; pedúnculo 3,5-4,8 cm compr., glabro; brácteas inconspícuas. Flores róseas; pedicelo 1,3-2,3 cm compr., glabro; lacínios do cálice ca. $5 \mathrm{~mm}$ compr., glabros, triangulares, eretos; coléteres calicinais presentes; corola dextrorsa, infundibiliforme, lobos 1,8-3 cm compr., patentes, obovais-arredondados com ápice agudo, glabros; tubo superior 2-2,5 cm compr., campanulado, tubo inferior ca. $2,5 \mathrm{~cm}$ compr., cilíndrico; anteras parcialmente adnatas à cabeça do estilete, inclusas, ca. $8 \mathrm{~mm}$ compr., estreito lanceoladas com ápice apiculado; nectários 2, livres, oblongos; ovário ca. $3 \mathrm{~mm}$ compr., ovóide, glabro; estilete. ca. $20 \mathrm{~mm}$ compr., cabeça do estilete ca. $3 \mathrm{~mm}$ compr., cônica, pentacostada, ápice bilobado. Folículos ca. $20 \mathrm{~cm}$ compr., cilíndricos, castanhos, glabros; sementes lineares, sem prolongamento apical, coma amarelada. Material examinado: BRASIL. Minas Gerais: Rio Preto, Serra Negra, Cachoeira do Ninho da Égua, 25-II-2005, fl., fr., C.N. Matozinhos et al. 212 (CESJ); Trilha para o Ninho da Égua, 9-XI-2005, fl., C.N. Matozinhos et al. 246 (CESJ); 20-I-2006, fl., V. Belchior et al. 3 (CESJ); 1-IV-2008, fl., fr., C.N. Matozinhos \& N.L. Abreu 342 (CESJ, R).

Ocorre no Brasil nos Estados de Minas Gerais, Rio de Janeiro e São Paulo, de forma restrita ao longo da Cadeia do Espinhaço, Serra da Bocaina (Sales 1993) e Serra da Mantiqueira. Na Serra Negra está presente principalmente nas áreas campestres, mas também foi encontrada nas orlas das matas nebulares.

Mandevilla sellowii possui grandes flores róseas de fauce amarela que tornam fácil sua identificação no campo. Exibe afinidades vegetativas com M. atroviolacea e $M$. pendula, o que em coleções de herbário pode gerar identificações equivocadas, caso não haja indicação de coloração das flores nos rótulos.

16. Mandevilla tenuifolia (J.C. Mikan) Woodson, Ann. Missouri Bot. Gard. 20: 679. 1933. Figura $6 \mathrm{~d}-\mathrm{h}$

Herbácea ou subarbustiva, ca. $50 \mathrm{~cm}$ alt.; ramos 
cilíndricos, escabros, violáceos na porção mais basal, lisos; coléteres nodais glandulares, diminutos. Folhas opostas; pecíolo 0,2-0,35 cm compr., cilíndrico, canaliculado; lâmina 4,5-8,8 × 0,3-1 cm, membranácea a cartácea, linear a estreito elíptica, ápice acuminado, base atenuada, margem levemente revoluta face adaxial escabra, opaca, face abaxial glabra; domácias ausentes; coléteres presentes. Inflorescência axilar a subaxilar, 2-5-flora; pedúnculo 4-13 cm compr., glabro; brácteas diminutas, estreito-lanceoladas. Flores róseas a roxas, lilases a púrpuras; pedicelo 0,7-1,8 cm compr., glabro; lacínios do cálice 4,1-5,1 mm compr., glabros, lanceolados, eretos; coléteres calicinais presentes; corola dextrorsa, hipocrateriforme, lobos $0,8-1,2 \times 0,6-0,7 \mathrm{~cm}$, patentes, oblíquos-obovados com ápice agudo a obtuso, glabros; tubo único 1,5-2 cm compr., cilíndrico; anteras parcialmente adnatas à cabeça do estilete, inclusas, ca. $3 \mathrm{~mm}$ compr., oblongo lanceoladas com ápice curto apiculado; nectários 2, livres, ovados; ovário 0,8-0,9 mm compr., ovóide, glabro; estilete ca. $12 \mathrm{~mm}$ compr., cabeça do estilete ca. $1 \mathrm{~mm}$ compr., cônica, ápice curto-apiculado. Folículos 4,5-6 cm compr., cilíndricos, castanhos, glabros; sementes estreito-oblongas, sem prolongamento apical, coma amarelada.

Material examinado: BRASIL. Minas Gerais: Rio Preto, Serra Negra, Fazenda da Tiririca, 15-XI-2003, fl., fr., F.R. Salimena et al. 1141 (CESJ); 23-II-2004, fl., F.R. Salimena et al. 1245 (CESJ, R); RPPN São Lourenço do Funil, 7-XII-2007, fl., F.R. Salimena et al. 2577 (CESJ); Trilha para a Cachoeira do Marciano, 14-X-2008, fl., C.N. Matozinhos \& N.L. Abreu 418 (CESJ); Lima Duarte, Serra Negra, Fazenda Serra Negra, Cachoeira da Borboleta Azul, 1-III-2008, fl., F.R. Salimena et al. 2655 (CESJ); Estrada para Monte Verde de Cima, 15-XI-2008, fl., F.R. Salimena \& P.H. Nobre 2754 (CESJ); RPPN Fazenda Serra Negra, 4-IV-2009, fr., S.A. Roman et al. 80 (CESJ).

Espécie amplamente distribuída no Brasil, não ocorrendo somente na região Sul. Habita os mais diversos ambientes, principalmente campestres, cerrados e até caatinga (Sales 1993). É muito frequente nos campos arenosos e afloramentos rochosos da Serra Negra.

Mandevilla tenuifolia forma pequenas populações, e suas flores têm uma diversidade de tons que transitam do rosa mais claro chegando a quase vermelhas e por vezes lilases ou até roxas. As folhas também têm aspectos variados, apresentado alta plasticidade e polimorfismo.

\section{Orthosia Decne.}

O gênero é neotropical, possui cerca de 40 espécies distribuídas da Flórida a Argentina, com o centro de diversidade sendo o Brasil (Liede-Schumann \& Meve 2008). Na Serra Negra foi registrada a espécie Orthosia scoparia.

17. Orthosia scoparia (Nuttal) Liede \& Meve, Novon 18: 207. 2008.

Figura 7 g-i

Subarbusto; ramos eretos a volúveis glabrescentes a unilateralmente pubescentes, esverdeados; coléteres nodais ausentes. Folhas opostas, caducas na floração; pecíolo 0,5-1 mm compr., glabro; lâmina 0,6-1,8 × 0,5-1 cm, membranácea, lineares, ápice agudo, base cuneada, margem plana, glabras em ambas as faces; coléteres foliares ausentes. Inflorescência subaxilar, fasciculiforme, por vezes reduzida a uma única flor; pedúnculo inconspícuo, pubescente; brácteas diminutas, puberulentas. Flores vináceas, pedicelo 1-2 mm compr., puberulento; lacínios do cálice $0,2-0,5 \times$ ca. $0,4 \mathrm{~mm}$, ovais, externamente puberulentos; coléteres calicinais presentes; corola dextrorsa, rotácea, lobos ca. $2 \times 0,8 \mathrm{~mm}$, patentes a reflexos, lanceolados, externamente glabros, internamente papilosos; tubo ca. $0,5 \mathrm{~mm}$ compr.; corona simples; segmentos ca. $0,5 \times 0,5 \mathrm{~mm}$, alvacentos, arredondados, concrescidos na base formando um anel, mais baixos que o ginostégio. Ginostégio séssil; cabeça do estilete com ápice mamilado; anteras trapezoidais, asas mais longas que o dorso, apêndice membranáceo oval, inflexo sobre o ginostégio. Corpúsculo $0,11-0,13 \times$ ca. $0,03 \mathrm{~mm}$, sagitiforme; caudículas ca. $0,06 \mathrm{~mm}$ compr., oblíquas descendentes, cilíndrica, inseridas no ápice das polínias; polínias ca. $0,11 \times 0,05 \mathrm{~mm}$, claviformes. Folículo 4,5-5,5 cm compr., fusiforme, glabro; sementes fusiformes, coma alvacenta.

Material examinado: BRASIL. MinAs Gerais: Rio Preto, Serra Negra, Trilha para a cachoeira do Ninho da Égua, 22-IV-2005, fl., C.N. Matozinhos et al. 233 (CESJ, R); Região do Burro de Ouro, 20-V-2006, fl., fr., P.L. Vianna et al. 2061 (CESJ); Ninho da Égua, I-V-2009, fl., C.N. Matozinhos et al. 444 (CESJ).

Ocorre no Brasil em todos os Estados das regiões Sul e Sudeste. Segundo Liede-Schumann \& Meve 


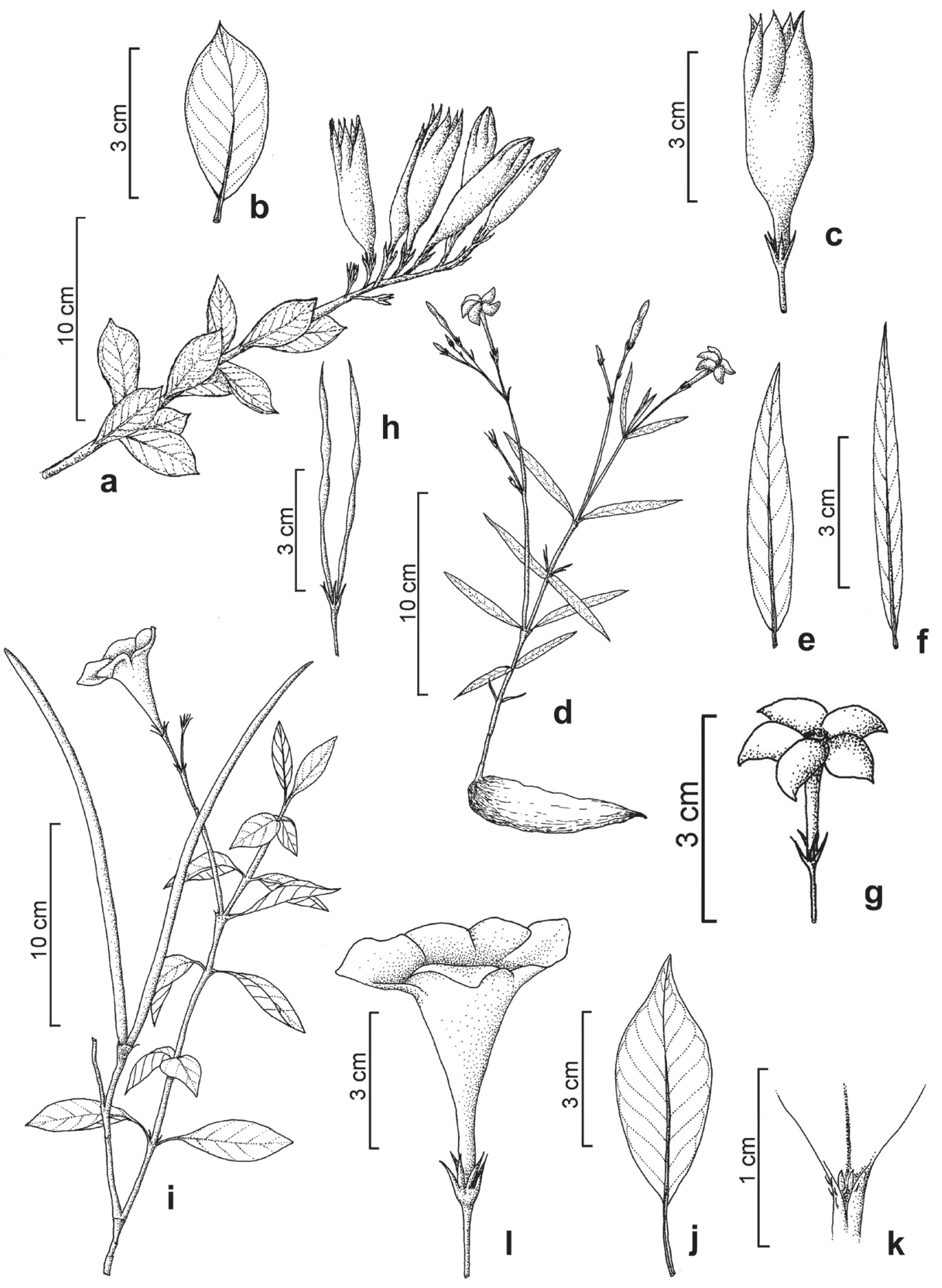

Figura 6. a-c. Mandevilla pendula. a. Ramo florífero. b. Detalhe da folha. c. Flor. d-h. Mandevilla tenuifolia. d. Hábito. e-f. Variação foliar. g. Flor. h. Fruto. i-l. Mandevilla sellowii. i. Ramo com flores e fruto. j. Folha. k. Detalhe dos coléteres foliares. 1. Flor (a-c: Matozinhos \& Abreu 417; d, f, h: Matozinhos \& Abreu 438, e, g: Salimena et al. 1141; i-1: Matozinhos \& Abreu 342).

Figure 6. a-c. Mandevilla pendula. a. Flowering branch. b. Leaf. c. Flower. d-h. Mandevilla tenuifolia. d. Habit. e-f. Foliar variation. g. Flower. h. Fruit. i-l. Mandevilla sellowii. i. Branch with flower and fruit. j. Leaf. k. Leaf base showing foliar colleters. 1. Flower (a-c: Matozinhos \& Abreu 417; d, f, h: Matozinhos \& Abreu 438, e, g: Salimena et al. 1141; i-1: Matozinhos \& Abreu 342). 
(2008), esta espécie apresenta distribuição na América do Sul e Central.

Orthosia scoparia tem sido erroneamente identificada como Tassadia subulata e suas variedades (Liede-Schumann \& Meve 2008). Possui o hábito subarbustivo, geralmente áfilo ou com folhas muito reduzidas no estágio de floração. Os ramos são eretos e clorofilados, com flores diminutas, vináceas.

Oxypetalum R. Br.

O gênero é exclusivo das regiões neotropicais, desde o sul da América Central até a Argentina (Farinaccio 2005). No Brasil possui cerca de 77 táxons, incluindo os infra-específicos (Marquete et al. 2007). Na Serra Negra está representado por três táxons: $O$. banksii subsp. banksii, $O$. alpinum var. alpinum e $O$. lanatum.

18. Oxypetalum alpinum (Vell.) Fontella \& E.A. Schwarz var. alpinum, Bol. Mus. Bot. Munic. 61: 2. 1984.

Figura 7 a-c

Trepadeira; ramos volúveis, glabros a puberulentos, esverdeados; coléteres nodais presentes. Folhas opostas; pecíolo 0,5-1,8 cm compr., pubescente; lâmina 3,5-9 ×0,6-2,4 cm, membranácea, lanceolada a oblanceolada, ápice agudo, base cordada a auriculada, margem plana, glabrescente em ambas as faces, coléteres foliares presentes. Inflorescência subaxilar, umbeliforme; pedúnculo 8-33 mm compr., pubescente; brácteas diminutas, pubescentes. Flores creme esverdeadas; pedicelo 5-17 mm compr., pubescente; lacínios do cálice 2,5-4 × 0,5-1 mm, lanceolados, externamente pubescentes; coléteres calicinais presentes; corola dextrorsa, campanulada a urceolada, lobos 10-12 × 2-3 mm, reflexos, torcidos no ápice, lanceolados, externamente pubescentes, internamente glabros; tubo ca. $4 \mathrm{~mm}$ compr.; corona simples; segmentos ca. $5 \times 1,3 \mathrm{~mm}$, alvacentos, subretangulares, ápice emarginado, mais altos que o ginostégio. Ginostégio subséssil; cabeça do estilete com ápice bífido, divergente; anteras subretangulares, asas menores que o dorso, apêndice membranáceo oval, ereto. Corpúsculo ca. $0,3 \times 0,1 \mathrm{~mm}$, elipsóide; caudículas ca. 0,25 mm compr., oblíquas descendentes, planas, inseridas no ápice das polínias; polínias $0,48-0,55 \times 0,15-0,25 \mathrm{~mm}$, oblongas. Fruto não observado.

Material examinado: BRASIL. Minas Gerais: Rio Preto, Serra Negra, Trilha para a Cachoeira da Água Amarela, 17-III-2007, fl., N.L. Abreu et al. 144 (CESJ).
Material adicional examinado: BRASIL. RIO DE Janeiro: Silva Jardim, Reserva Biológica de Poços das Antas, Juturnaíba, 17-VIII-1995, fl., J.M.A. Braga et al. 2715 (RB, MBM).

No Brasil ocorre nos Estados do Sudeste, exceto em São Paulo (Fontella-Pereira \& Schwarz 1984). Habita ambientes brejosos, florestas ou campos de altitude. Na Serra Negra foi coletada a variedade típica que apresenta a corola densamente pubescente, presente em áreas brejosas. Oxypetalum alpinum var. pallidum (Hoehne) Fontella \& E.A.Schwarz apresenta flores glabras a glabrescentes e ocorre nos Estados de São Paulo, Paraná e Santa Catarina.

19. Oxypetalum banksii Schult. subsp. banksii, Syst. Veg. 6: 91. 1820.

Figura 7 d-f

Liana; ramos volúveis, tomentosos, alvacentos; coléteres nodais ausentes. Folhas opostas; pecíolo 1-4 cm compr., tomentoso; lâmina 2,3-6 × 1,2-3,9 cm, membranácea, cordiformes ou oblongas, ápice apiculado, base cordada, margem plana, face abaxial tomentosa, face adaxial puberulenta; coléteres presentes. Inflorescência subaxilar, corimbiforme; pedúnculo 5-9 mm compr., tomentoso; brácteas ca. $2 \mathrm{~mm}$ compr., tomentosas. Flores amarelo-esverdeadas; pedicelo 12-23 mm compr., tomentoso; lacínios do cálice ca. $4 \times 0,5 \mathrm{~mm}$, lanceolados, externamente tomentosos; coléteres calicinais presentes; corola dextrorsa, rotácea, lobos 20-25 × ca. $3 \mathrm{~mm}$, reflexos, torcidos no ápice, linear-lanceolados, externamente puberulentos, internamente papilosos; tubo inconspícuo; corona simples; segmentos ca. $3 \times 2 \mathrm{~mm}$, castanho-avermelhados, arredondados, ápice truncado, mais baixos que o ginostégio. Ginostégio séssil; cabeça do estilete com ápice bífido, divergente; anteras subretangulares, asas tão longas quanto dorso, apêndice membranáceo oblongo, inflexo sobre o ginostégio. Corpúsculo 1,37-1,62 × 0,25-0,37 mm, subclaviforme; caudículas 0,75-1,0 mm compr., horizontais, planas com um dente lateral de ápice curvo, inseridas no ápice das polínias; polínias 1,12-1,25 × 0,12-0,22 mm, falciformes. Fruto não observado.

Material examinado: BRASIL. Minas Gerais: Rio Preto, Serra Negra, Vila do Funil, 1-IV-2006, fl., P.L. Vianna et al. 2021 (CESJ); Atrás da Gruta do Funil, 1-V-2009, fl., C.N. Matozinhos et al. 443 (CESJ, R). 
Ocorre no Brasil nos Estados da Bahia, Espírito Santo, Goías, Minas Gerais, Paraná, Rio de Janeiro, Rio Grande do Sul, Santa Catarina, São Paulo e no Distrito Federal em restingas, florestas secundárias e áreas antropizadas. Na Serra Negra foi registrada em áreas antropizadas.

Oxypetalum banksii subsp. banksii, caracteriza-se principalmente por apresentar os segmentos da corona e o ápice da cabeça do estilete vinosos, enquanto que Oxypetalum banksii subsp. corymbiferum Fontella \& Valente apresenta os segmentos da corona e o ápice da cabeça do estilete alvos ou verde-pálidos (Farinaccio 2005), sendo esta endêmica das restingas do Estado do Rio de Janeiro (Marquete et al. 2007).

20. Oxypetalum lanatum Decne. ex E. Fourn. in Mart., Fl. Bras. 6(4): 266. 1885.

Figura 8 a-e

Trepadeira; ramos volúveis, lanosos, castanho-esverdeados; coléteres nodais ausentes. Folhas opostas; pecíolo 0,3-2 cm compr., lanoso; lâmina 3,5-6 × 1,5-3 cm, cartácea a coriácea, oblongas a ovais, ápice mucronado, base cordada, margem plana, face abaxial lanosa, face adaxial pubescente; coléteres presentes. Inflorescência subaxilar, umbeliforme; pedúnculo 8-15 mm compr., lanoso; brácteas ca. $5 \mathrm{~mm}$ compr., pilosas. Flores creme-esverdeadas; pedicelo 10-15 mm compr., lanoso; lacínios do cálice ca. $8 \times 2 \mathrm{~mm}$, lanceolados, externamente lanosos; coléteres calicinais presentes; corola dextrorsa, subcampanulada a rotácea, lobos 18-20 × 6-8 $\mathrm{mm}$, patentes, torcidos no ápice, oblongos, externamente seríceos, internamente pilosos; tubo 4-8 $\mathrm{mm}$ compr.; corona simples; segmentos 4-3,5 × ca. $3 \mathrm{~mm}$, alvacentos, retangulares, ápice bilobado, apêndice filiforme ventral, mais altos que o ginostégio. Ginostégio séssil; cabeça do estilete com ápice bífido, convergente; anteras espatuladas, asas mais longas que o dorso, apêndice membranáceo oblongo, inflexo sobre o ginostégio. Corpúsculo ca. 1,45 $\times 0,5 \mathrm{~mm}$, oblongo a retangular; caudículas $0,42-0,5 \mathrm{~mm}$ compr., horizontais, planas com um dente lateral, inseridas no ápice das polínias; polínias 0,5-0,6 × 0,12-0,15 mm, elipsóides. Folículo ca. 7,5 cm compr., fusiforme, tomentoso; sementes piriformes, coma alvacenta.

Material examinado: BRASIL. Minas Gerais: Rio Preto, Serra Negra, Trilha para o Ninho da égua, 9-XI-2005, fl., C.N. Matozinhos et al. 264 (CESJ); 21-I-2006, fl., T. Konno et al. 861 (CESJ); Região do Burro de Ouro, 20-V-2006, fl., P.L. Vianna et al. 2064 (CESJ); 10-IV-2007, fr., F.S. Souza et al. 260 (CESJ);
Ninho da égua, 10-XII-2008, fl., C.N. Matozinhos 437 \& N.L. Abreu (CESJ, R).

No Brasil ocorre nos Estados de Minas Gerais e Rio de Janeiro, em florestas ombrófilas, florestas de galeria, campos de altitude e campos rupestre entre 1.000-1.400 m de altitude. Na Serra Negra foi coletada nas áreas campestres.

Dentre os Oxypetalum ocorrentes na área de estudo, esta espécie é facilmente reconhecida pela coloração creme esverdeada, flores grandes e vistosas, além do indumento lanoso por toda planta.

\section{Peplonia Decne.}

Gênero endêmico do Brasil, tendo como centro de diversidade o Estado do Rio de Janeiro (Rapini et al. 2004). A partir da transferência de cinco táxons de Gonioanthela para o gênero Peplonia, este engloba, agora, seis espécies. Na Serra Negra, encontramos apenas a espécie Peplonia organensis.

21. Peplonia organensis (E. Fourn.) Fontella \& Rapini, Kew Bull. 59(4): 537. 2005.

Figura $8 \mathrm{f}$-h

Liana; ramos volúveis, glabros, esverdeados; coléteres nodais presentes. Folhas opostas; pecíolo 0,6-1,5 cm compr., glabro; lâmina 3-7,5 × 1-2,6 cm, membranácea, elíptica a lanceolada, ápice agudo a acuminado, base cuneada, margem plana, glabras em ambas as faces; coléteres presentes. Inflorescência axilar, umbeliformes; pedúnculo ca. $2 \mathrm{~mm}$ compr., glabro; brácteas diminutas, glabras. Flores esverdeadas, cremes ou amarelas; pedicelo 2-4,5 mm compr., glabro; lacínios do cálice ca. $1,3 \times 1 \mathrm{~mm}$, ovais, glabros; coléteres calicinais ausentes; corola dextrorsa, urceolada, lobos 2,5-3 × 1-1,5 mm, eretos, reflexos no ápice, ovais, externamente glabros, internamente papiloso-barbelados; tubo ca. $1 \mathrm{~mm}$ compr.; corona simples; segmentos ca. 1,5 $\times 0,5 \mathrm{~mm}$, alvacentos, lineares, mais baixos que o ginostégio. Ginostégio séssil; cabeça do estilete com ápice mamilado; anteras trapezoidais, asas mais longas que o dorso, apêndice membranáceo suborbicular, ereto. Corpúsculo ca. $0,2 \times 0,11-0,12 \mathrm{~mm}$, subelipsóide; caudículas ca. 0,11 mm compr., oblíquas descendentes, cilíndrica, inseridas no ápice das polínias; polínias 0,32-0,35 × 0,11-0,15 mm, oblongas. Folículo ca. $6,5 \mathrm{~cm}$ compr., fusiforme, glabro; sementes elípticas, coma alvacenta.

Material examinado: BRASIL. Minas Gerais: Rio Preto, Serra Negra, Trilha para a Cachoeira do Ninho 


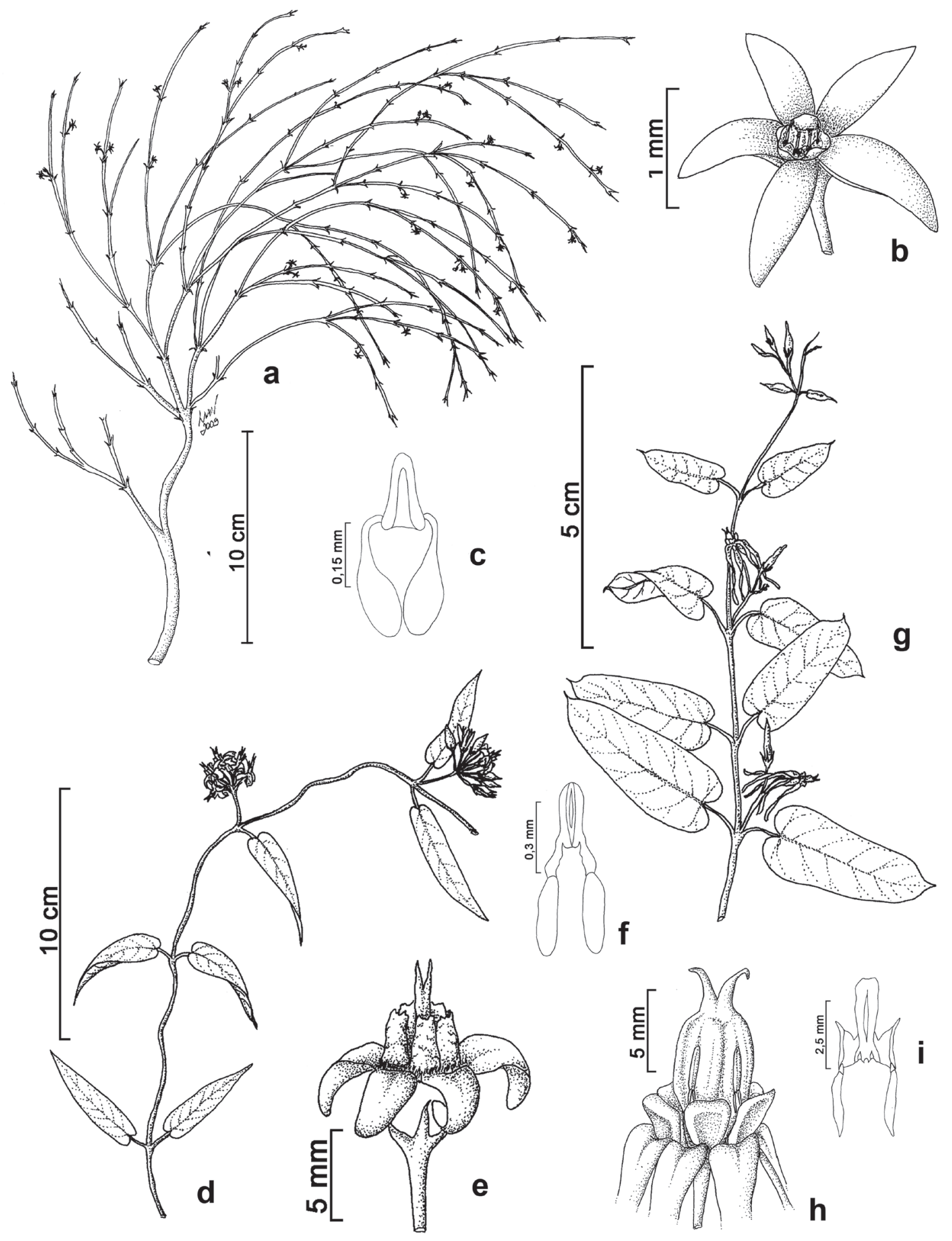

Figura 7. a-c. Orthosia scoparia. a. Ramo florífero. b. Flor. c. Polinário. d-f. Oxypetalum alpinum var. alpinum. d. Ramo florífero. e. Flor. f. Polinário. g-i. Oxypetalum banksii subsp. banksii. g. Ramo florífero. h. Flor. i. Polinário (a-c: Matozinhos et al. 233; d-f: Abreu et al. 144; f-i: Viana et al. 2021).

Figure 7. a-c. Orthosia scoparia. a. Flowering branch. b. Flower. c. Pollinarium. d-f. Oxypetalum alpinum var. alpinum. d. Flowering branch. e. Flower. f. Pollinarium. g-i. Oxypetalum banksii subsp. banksii. g. Flowering branch. h. Flower. i. Pollinarium (a-c: Matozinhos et al. 233; d-f: Abreu et al. 144; g-i: Viana et al. 2021). 
da Égua, 3-IV-2006, fl., T. Konno et al. 867 (CESJ); 27-I-2007, fl., L. Menini Neto et al. 282 (CESJ); Região do Burro de Ouro, 10-IV-2007, fl., N.L. Abreu et al. 193 (CESJ); Ninho da Égua, 10-XII-2008, C.N. Matozinhos \& N.L. Abreu 435 (CESJ); Atrás da Gruta do Funil, 1-V-2009, fl., C.N. Matozinhos et al. 440 (CESJ, R); Trilha atrás da Gruta do Funil, 3-II-2009, fl., fr., N.L. Abreu et al. 309 (CESJ).

Ocorre no Brasil, nos Estados de Minas Gerais, Rio de Janeiro e São Paulo. Na Serra Negra ocorre principalmente nos campos de altitude e orlas das matas nebulares.

Espécie facilmente reconhecida, dentre as ocorrentes na Serra Negra, pelas folhas discolores e ramos acastanhados, com coléteres nodais evidentes, bem como a inflorescência curto-pedunculada e flores urceoladas.

\section{Prestonia R. Br.}

Gênero que ocorre predominantemente na América tropical, desde as Antilhas até o sul do Brasil e norte da Argentina (Rio \& Kinoshita 2005). Apresenta 60 espécies, sendo 25 encontradas no Brasil. Na Serra Negra o gênero está representado por apenas uma espécie, Prestonia coalita, considerada a espécie mais amplamente distribuída do gênero no Sul e Sudeste Brasileiro.

22. Prestonia coalita (Vell.) Woodson, Ann. Missouri Bot. Gard. 18: 552. 1931.

Figura $8 \mathrm{i}-\mathrm{j}$

Liana delgada; ramos cilíndricos, glabros, acinzentados, levemente verrugosos; coléteres nodais glandulares, diminutos. Folhas opostas; pecíolo 0,8-1 cm compr., cilíndrico, canaliculado; lâmina 5-9,5 × 2,6-3,8 cm, membranácea, elíptica a oblanceolada, ápice agudo a acuminado, base atenuada, margem lisa, face adaxial glabra, brilhante, face abaxial puberulenta; domácias ausentes; coléteres foliares ausentes. Inflorescência axilar, 3-4 flores; pedúnculo ca. $0,5 \mathrm{~cm}$ compr., pubescente; brácteas 1-2 mm compr., lanceoladas. Flores amarelas; pedicelo 0,5-0,8 cm compr., puberulento; lacínios do cálice ca. $5 \mathrm{~mm}$ compr., glabros, lineares, suberetos; coléteres calicinais presentes; corola dextrorsa, hipocrateriforme, lobos ca. $0,5 \times 0,8 \mathrm{~cm}$, patentes, obovais com ápice truncado, glabros; tubo único ca. 1,5 cm compr., cilíndrico, dilatado na base, anel carnoso na fauce; anteras parcialmente adnatas à cabeça do estilete, inclusas, ca. $5 \mathrm{~mm}$ compr., lanceoladas com ápice agudo; nectários 5, unidos oblongos; ovário ca. 1,5 mm compr., ovóide, glabro; estilete ca. $9 \mathrm{~mm}$ compr., cabeça do estilete ca. $0,3 \mathrm{~mm}$ compr., cônica, ápice bífido. Frutos não observados.

Material examinado: BRASIL. MinAs GerAis: Lima Duarte, Serra Negra, RPPN Fazenda Serra Negra, Cachoeira da Mamãe Oxum, 2-VIII-2008, fl., F.R. Salimena et al. 2684 (CESJ).

Ocorre no Brasil nos Estados do Ceará, Mato Grosso, Minas Gerais, Rio de Janeiro, São Paulo, Paraná e Rio Grande do Sul, em floresta estacional semidecidual, cerrado, caatinga e, mais raramente, restinga. Contudo, na Serra Negra foi coletada em área de floresta ombrófila, como igualmente apontado por Quinet (2009).

\section{Tabernaemontana $\mathrm{L}$.}

Gênero de distribuição Pantropical, englobando cerca de 110 espécies. No Brasil ocorrem aproximadamente 23 espécies, sendo sete endêmicas (Koch \& Kinoshita 2005). Na Serra Negra encontramos duas espécies, de ocorrência comum no Sudeste e Sul do Brasil: T. catharinensis e T. hystrix.

23. Tabernaemontana catharinensis A. DC., Prodr. 8: 365.1844.

Figura $9 \mathrm{a}-\mathrm{b}$

Árvore ou arvoreta, ca. $4 \mathrm{~m}$ alt.; ramos cilíndricos, glabros, castanhos a levemente acinzentados, por vezes lenticelados, rugosos; coléteres nodais ausentes. Folhas opostas, distribuídas ao longo dos ramos; pecíolo 1-1,6 cm compr., contorto, canaliculado; lâmina 6,5-15 × 1,6-3,6 cm, cartácea a coriácea, elíptica a lanceolada, ápice acuminado a cuspidado, base atenuada, margem lisa, face adaxial glabra, brilhante, face abaxial glabra, domácias ausentes; coléteres ausentes. Inflorescência axilar, multiflora; pedúnculo 2,1-2,9 cm compr., glabro; brácteas ca. $0,2 \times 0,1 \mathrm{~cm}$, lanceoladas. Flores amarelas ou alvas; pedicelo $0,5-0,8 \mathrm{~cm}$ compr., glabro; lacínios do cálice $2-4 \times$ ca. $2 \mathrm{~mm}$, glabros, obovados com ápice agudo, eretos a subpatentes; coléteres calicinais dentiformes, fundidos na base; corola sinistrorsa, hipocrateriforme, lobos 0,6-0,8 $\times 0,6 \mathrm{~cm}$, dolabriformes, patentes, obovado-arredondados com ápice acuminado, pilosos na base; tubo ca. 0,6 cm compr., cilíndrico, dilatado na base; anteras livres, inclusas, ca. $4 \mathrm{~mm}$ compr., sagitadas, ápice agudo; nectários ausentes; ovário ca. 2 mm compr., ovóide, glabro; estilete $0,5-1 \mathrm{~mm}$ compr., cabeça do estilete ca. 1,5 mm compr., cilíndrica. Frutos não observados. 

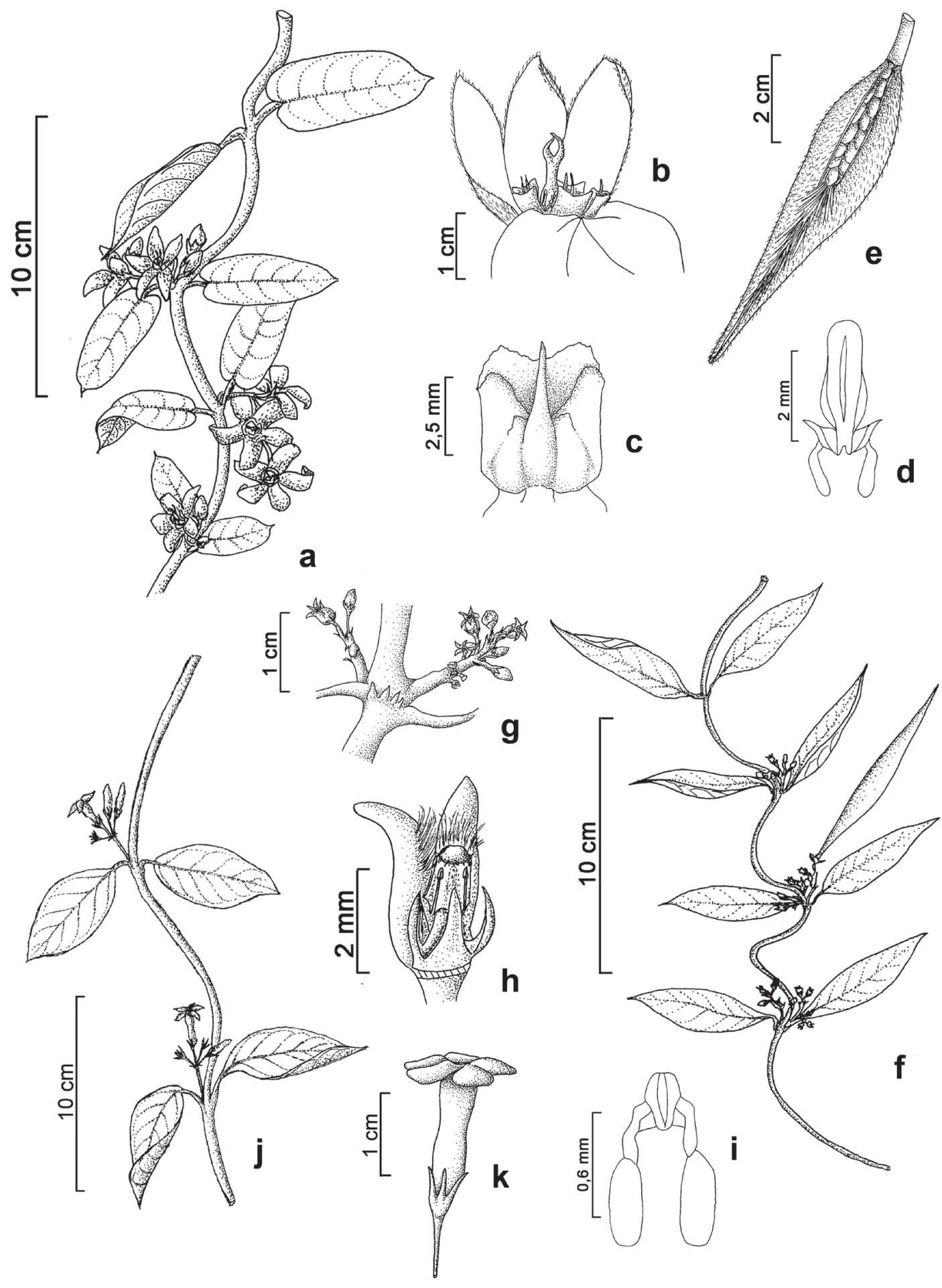

Figura 8. a-e. Oxypetalum lanatum. a. Ramo florífero. b. Flor. c. Vista ventral da corona. d. Polinário. e. Fruto. f-i. Peplonia organensis. f. Ramo florífero. g. Inflorescência e coléteres nodais. h. Detalhe do ginostégio e corona. i. Polinário. j-k. Prestonia coalita. i. Ramo florífero. j. Flor (a-d: Matozinhos \& Abreu 457; e: Souza et al. 260; f-i: Abreu et al. 309; j-k: Salimena et al. 2684).

Figure 8. a-e. Oxypetalum lanatum. a. Flowering branch. b. Flower. c. Corona segments in ventral view. d. Pollinarium. e. Fruit. f-i. Peplonia organensis. f. Flowering branch. g. Inflorescence and triangular colleters in stem node. h. Gynostegium with corona. i. Pollinarium. j-k. Prestonia coalita. i. Flowering branch. j. Flower (a-d: Matozinhos \& Abreu 457; e: Souza et al. 260; f-i: Abreu et al. 309; j-k: Salimena et al. 2684). 

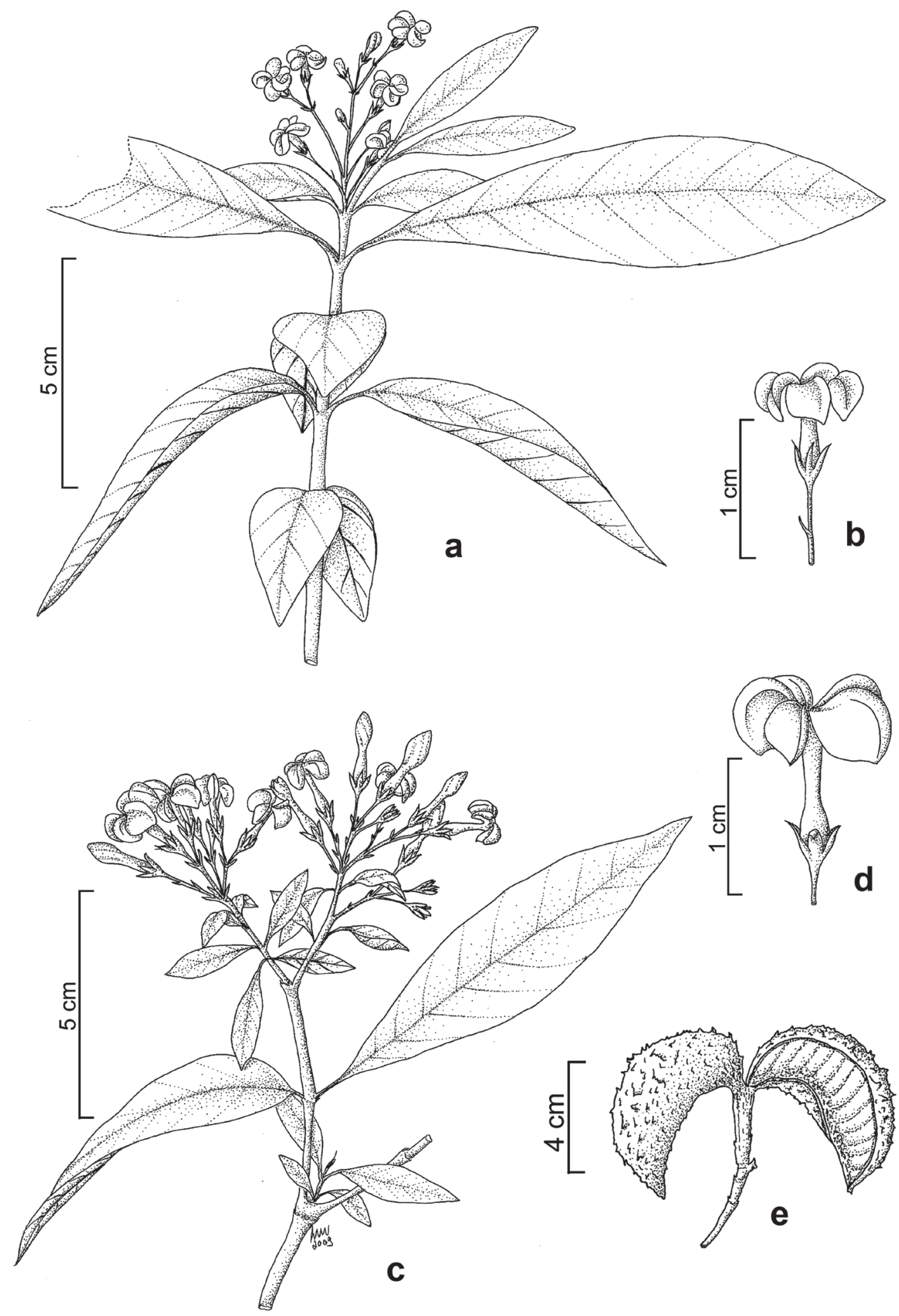

Figura 9. a-b. Tabernaemontana catharinensis. a. Ramo florífero. b. flor. c-e. Tabernaemontana hystrix. c. Ramo florífero. d. Flor. e. Fruto (a-b: Costa et al. 41; c-e: Salimena et al. 1133).

Figure 9. a-b. Tabernaemontana catharinensis. a. Flowering branch. b. Flower. c-e. Tabernaemontana hystrix. c. Flowering branch. d. Flower. e. Fruit (a-b: Costa et al. 41; c-e: Salimena et al. 1133). 
Material examinado: BRASIL. Minas Gerais: Rio Preto, Serra Negra, Fazenda da Tiririca, 15-XI-2003, fl., F.R. Salimena et al. 1134 (CESJ); 13-XI-2004, fl., C.N. Matozinhos et al. 143 (CESJ, R); 10-V-2008, fl., I.A. Costa \& P.H. Nobre 41 (CESJ, R); Mata do Benedito, 2007, fl., A.S.M. Valente \& P.O. Garcia s.n. (CESJ49367).

'No Brasil distribui-se amplamente, ocorrendo nos Estados da Bahia, Ceará, Espírito Santo, Mato Grosso do Sul, Minas Gerais, Paraná, Rio de Janeiro, Rio Grande do Sul, Santa Catarina, São Paulo e no Distrito Federal. Na Serra Negra ocorre em interior e borda de mata, além de áreas campestres e, por vezes, degradadas.

Tabernaemontana catharinensis é conhecida como "praga das pastagens". Tem sido muito confundida com T. hystrix (Kock \& Kinoshita 1999, Matozinhos \& Konno 2008), porém esta última apresenta flores maiores e tubo da corola mais longo, além de folhas comparativamente mais delgadas.

24. Tabernaemontana hystrix Steud., Nomencl. Bot., ed. 2, 2: 658. 1841.

Figura 9 c-e

Árvore ou arvoreta, 3-4 m alt.; ramos cilíndricos, glabros, castanhos a levemente acinzentados, por vezes lenticelados nos ramos jovens, rugosos; coléteres nodais ausentes. Folhas opostas, congestas no ápice dos ramos; pecíolo 0,6-1,5 cm compr., contorto, levemente canaliculado; lâmina 3,9-12,5 × 1,5-3 cm, cartácea, elíptica a lanceolada, ápice acuminado a cuspidado, base atenuada, margem lisa, face adaxial glabra, opaca, face abaxial glabra, domácias ausentes; coléteres ausentes. Inflorescência axilar, multiflora; pedúnculo 1,2-3,2 cm, glabro; brácteas 0,3-0,8 $\times$ ca. $0,2 \mathrm{~cm}$, lanceoladas. Flores amarelas ou alvas; pedicelo 0,8-1,8 cm compr., glabro; lacínios do cálice 3-6 × ca. $2 \mathrm{~mm}$, glabros, lanceolados, reflexos; coléteres calicinais dentiformes, fundidos na base; corola sinistrorsa, hipocrateriforme, lobos 0,8-1 × 1-1,2 cm, dolabriformes, patentes, obovais-arredondados, ápice retuso, glabros; tubo 1,2-1,4 cm compr., cilíndrico, dilatado na base; anteras livres, inclusas, ca. $5 \mathrm{~mm}$ compr., sagitadas, ápice agudo; nectários ausentes; ovário ca. $3 \mathrm{~mm}$ compr., oblongo, glabro; estilete ca. $2 \mathrm{~mm}$ compr., cabeça do estilete 1-1,5 mm compr., cilíndrica. Folículos ca. 5,3 $\times 2 \mathrm{~cm}$ reniformes, esverdeados, muricados; sementes ovaladas, arilo alaranjado.
Material examinado: BRASIL. Minas Gerais: Rio Preto, Serra Negra, Fazenda da Tiririca, 3-XI-2003, fl., F.R. Salimena \& P.H. Nobre 1133 (CESJ); 24-IV-2004, fl., fr., K. Antunes et al. 98 (CESJ); Estrada Rio Preto-Vilarejo do Funil, 11-IV-2004, fr., K. Antunes \& C.N. Matozinhos 81 (CESJ); s.d., fr., C.N. Matozinhos et al. 332 (CESJ); 30-VIII-2008, Trilha para Cachoeira do Marciano, fl., fr., C.N. Matozinhos et al. 407 (CESJ, R).

Ocorre no Brasil nos Estados da Bahia, Espírito Santo, Mato Grosso do Sul, Minas Gerais, Paraná, Rio de Janeiro, São Paulo e no Distrito Federal, preferencialmente em locais abertos. Na Serra Negra é encontrada principalmente na margem de estradas, ou em campos arenosos e áreas degradadas.

Segundo Koch \& Kinoshita (2005), em São Paulo, T. hystrix apresenta forte polimorfismo em caracteres como a consistência e a distribuição das folhas nos ramos, além do tamanho das flores. A delimitação morfológica desta espécie torna-se ainda mais complexa, visto que o lectótipo é representado por uma estampa de Velloso. Desta forma, espécies de Tabernaemontana demandam ainda estudos taxonômicos mais profundos.

\section{Agradecimentos}

Ao CENPES (Petrobrás) pela bolsa de mestrado de CNM. A FAPERJ pelo apoio concedido a TK (E-26/170.839/2006). A Luiza Kinoshita e Jorge Fontella-Pereira pelas correções e comentários imprescindíveis a este trabalho. A Fátima Salimena curadora do herbário CESJ que gentilmente permitiu o acesso aos laboratórios da UFJF. Ao Luiz Menini-Neto pelas ilustrações. Aos revisores anônimos que tanto contribuíram para o aprimoramento deste trabalho.

\section{Literatura citada}

Assis, L.C.S. \& Mello-Silva, R. 2010. Three new species of Ocotea (Lauraceae) from the campos rupestres of Brazil. Brittonia 62: 86-94.

Batista, J.A.N., Mota, R.C., Abreu, N.L. \& Menini Neto, L. 2008. Habenaria pseudoglaucophylla (Orchidaceae), a new species from Minas Gerais, Brazil. Novon 18: 409-414.

Endress, P.K. 1994. Diversity and evolutionary biology of tropical flowers. Cambridge University Press, Cambridge.

Ezcurra, C. 1981. Revisión de las apocináceas de la Argentina. Darwiniana 23: 367-474. 
Fallen, M.E. 1985. The gynoecial development and systematic position of Allamanda (Apocynaceae). American Journal of Botany 72: 572-579.

Farinaccio, M.A. \& Mello-Silva, R. 2004. Asclepiadoideae (Apocynaceae) do Parque Nacional da Serra da Canastra, Minas Gerais, Brasil. Boletim de Botânica da Universidade de São Paulo 22: 53-92.

Farinaccio, M.A. 2005. Oxypetalum. In: M.G.L. Wanderley, G.J. Shepherd, T.S. Melhem \& A.M. Giulietti (eds.). Flora Fanerogâmica do Estado de São Paulo. FAPESP \& Rima, São Paulo, v. 4, pp. 130-150.

Farinaccio, M.A. 2007. Sistemática Molecular de Oxypetalum R. Br. (Apocynaceae, Asclepiadoideae). Tese de doutorado, Universidade de São Paulo, São Paulo. (http://www.teses.usp.br/teses/disponiveis/41/41132/ tde-02062008-143035/pt-br.php (acesso em 25.01.2011)

Fontella-Pereira, J. (coord.) 2005. Asclepiadaceae. In: M.G.L. Wanderley, G.J. Shepherd, T.S. Melhem \& A.M. Giulietti (eds.). Flora Fanerogâmica do Estado de São Paulo. FAPESP \& Rima, São Paulo. v. 4, pp. 93-156.

Fontella-Pereira, J. \& Ferreira, M.V. 2005. O gênero Macroditassa (Apocynaceae - Asclepiadoideae) no Brasil. Bonplandia 14: 7-34.

Fontella-Pereira, J. \& Konno, T.U.P. 2005. Asclepias (Asclepiadaceae). In: M.G.L. Wanderley, G.J. Shepherd, T.S. Melhem \& A.M. Giulietti (eds.). Flora Fanerogâmica do Estado de São Paulo. FAPESP \& Rima, São Paulo, v. 4, pp. 98-100.

Fontella-Pereira, \& Schwarz, E.A. 1984. Contribuição ao estudo das Asclepiadaceae brasileiras, XIX. Uma nova espécie de Gonolobus Mich. e novas combinações em Oxypetalum R.Br. Boletim do Museu Botânico Municipal 61: 1-7.

Fontella-Pereira, J., Valente, M.C. \& Schwarz, E.A. 1984. Contribuição ao estudo das Asclepiadaceae brasileiras, XXI. Asclepiadaceae do município de Ouro Preto, Estado de Minas Gerais - uma sinopse. Boletim do Museu Botânico Kuhlmann 7: 63-127.

Fontella-Pereira, J., Valente, M.C. \& Marquete, F.S.N. 1987. Asclepiadaceae. In: A.M. Giulietti, N.L. Menezes, J.R. Pirani, M. Meguro \& M.G.L. Wanderley. Flora da Serra do Cipó: Caracterização e lista das espécies. Boletim de Botânica da Universidade de São Paulo 9: 22-24.

Gomes, S.M. \& Cavalcanti, T.B. 2001. Morfologia floral de Aspidosperma Mart. \& Zucc. (Apocynaceae). Acta Botanica Brasilica 15: 73-88.

Harris, J.G. \& Harris, M.W. 2001. Plant identification terminology: an illustrated glossary. 2 ed. Spring Lake Publishing, Spring Lake.

IBGE. 2006. Mapa municipal estatístico, Rio Preto, escala 1:50.000, folhas 2714-1 e 2680-3, Instituto Brasileiro de Geografia e Estatística, Rio de Janeiro. http://www. ibge.gov.br (acesso em 25.01.2011).
Judd, W.S., Campbell, C.S., Kellogg, E.A., Stevens, P.F. \& Donoghue, M.J. 2009. Sistemática vegetal: um enfoque filogenético. 3 ed. Artmed, Porto Alegre.

Kinoshita, L.S. 2005. Apocynaceae (coord.). In: M.G.L. Wanderley, G.J. Shepherd, T.S. Melhem \& A.M. Giulietti (eds.), Flora Fanerogâmica do Estado de São Paulo. FAPESP \& Rima, São Paulo, v. 4, pp. 35-91.

Koch, I. \& Kinoshita, L.S. 1999. As Apocynaceae da região de Bauru, SP. Acta Botanica Brasilica 13: 61-86.

Koch, I. \& Kinoshita, L.S. 2005. Tabernaemontana. In: M.G.L. Wanderley, G.J. Shepherd, T.S. Melhem \& A.M. Giulietti (eds.) Flora Fanerogâmica do Estado de São Paulo. FAPESP \& Rima, São Paulo, v. 4, pp. 83-86.

Konno, T.U.P. 1997. Asclepiadaceae R.Br. das Restingas do Estado do Rio de Janeiro. Dissertação de Mestrado, Museu Nacional, Universidade Federal do Rio de Janeiro, Rio de Janeiro.

Konno, T.U.P. 2005. Ditassa R. Br. no Brasil (Asclepiadoideae-Apocynaceae) e revisão taxonômica de Minaria T.U.P. Konno \& Rapini. Tese de Doutorado, Universidade de São Paulo, São Paulo.

Konno, T.U.P. \& Pereira, F.C. 2005. Ditassa. In: M.G.L. Wanderley, G.J. Shepherd, T.S. Melhem \& A.M. Giulietti (eds.), Flora Fanerogâmica do Estado de São Paulo. FAPESP \& Rima, São Paulo, v. 4, pp. 107-111.

Liede-Schumann, S. \& Meve, U. 2008. Nomenclatural novelties and new species in Orthosia (Apocynaceae, Asclepiadoideae). Novon 18: 202-210.

Marcondes-Ferreira, W. 1988. Aspidosperma Mart., nom. cons. (Apocynaceae): estudos taxonômicos. Tese de Doutorado, Universidade Estadual de Campinas, Campinas.

Marcondes-Ferreira, W. 2005. Aspidosperma In: M.G.L. Wanderley, G.J. Shepherd, T.S. Melhem \& A.M. Giulietti (eds.). Flora Fanerogâmica do Estado de São Paulo. FAPESP \& Rima, São Paulo, v. 4, pp. 39-47.

Marcondes-Ferreira, W. \& Kinoshita, L.S. 1996. Uma nova divisão infragenérica para Aspidosperma Mart. (Apocynaceae). Revista Brasileira de Botânica 19: 203-214.

Marquete, N.F.S., Fontella-Pereira, J., Valente, M.C. 2007. Asclepiadoideae (Apocynaceae) from southeastern Brazil. I. The genus Oxypetalum from Rio de Janeiro state, Brazil. Annals of the Missouri Botanical Garden 94: 435-462.

Matozinhos, C.N. \& Konno, T.U.P. 2008. A família Apocynaceae na Reserva Biológica do Grama-Descoberto, Minas Gerais, Brasil. Rodriguésia 59: 87-98.

Matozinhos, C.N. \& Konno, T.U.P. 2011. New Species of Macroditassa (Apocynaceae-Asclepiadoideae) from Minas Gerais, Brazil. Systematic Botany 36: 137-140. 
Menini-Neto, L., Matozinhos, C.N., Abreu, N.L., Valente, A.S.M., Antunes, K., Souza, F.S., Viana, P.L., Salimena, F.R.G. 2009. Flora não-arbórea de uma floresta de grota na Serra da Mantiqueira, Zona da Mata de Minas Gerais, Brasil. Biota Neotropica 9(4). http://www.biotaneotropica.org.br/v9n4 (acesso em 25.01.2011).

Monguilhott, L. \& Mello-Silva. 2008. Apocynaceae do Parque Estadual do Ibitipoca, Minas Gerais, Brasil. Boletim de Botânica da Universidade de São Paulo 26: 93-130.

Oliveira, A.A. \& Pirani, J.R. 2003. Flora de Grão-Mogol, Minas gerais: Apocynaceae s. l. (exceto Asclepiadoideae). Boletim Botânica da Universidade de São Paulo 21: 73-82.

Quinet, C.G.P. 2009. As subfamílias Rauvolfioideae e Apocynoideae (Apocynaceae) no Estado do Rio de Janeiro, Brasil. Tese de Doutorado, Universidade Federal do Rio de Janeiro, Rio de Janeiro.

Radford, A.E., Dickison, W.C., Massey, J.R. \& Bell, C.R. 1974. Vascular plant systematic. Harper \& Row Publishers, New York.

Rapini, A., Mello-Silva, R. \& Kawasaki, M.L. 2001. Asclepiadoideae (Apocynaceae) da Cadeia do Espinhaço de Minas Gerais, Brasil. Boletim de Botânica da Universidade de São Paulo 19: 55-169.

Rapini, A., Fontella-Pereira, J., Lamare, E.H. \& Liede-Schumann, S. 2004. Taxonomy of Peplonia (including Gonioanthela) and a reinterpretation of Orthosieae (Asclepiadoidea, Apocynaceae). Kew Bulletin 59: 531-539.
Rapini, A., Chase, M.W. \& Konno, T.U.P. 2006. Phylogenetics of South American Asclepiadaceae (Apocynaceae). Taxon 55: 119-124.

Rio, M.C.S. \& Kinoshita, L.S. 2005. Prestonia (Apocynaceae) no Sul e Sudeste do Brasil. Hoehnea 32: 233-258.

Sales, M.F. 1993. Estudos taxonômicos de Mandevilla Lindley subgênero Mandevilla (Apocynaceae) no Brasil. Tese de Doutorado, Universidade Estadual de Campinas, Campinas.

Sales, M.F. \& Kinoshita, L.S. 2005. Mandevilla. In: M.G.L. Wanderley, G.J. Shepherd, T.S. Melhem \& A.M. Giulietti (eds.), Flora Fanerogâmica do Estado de São Paulo. FAPESP \& Rima, São Paulo, v. 4, pp. 60-69.

Simões, A.O. \& Kinoshita, L.S. 2002. The Apocynaceae s. str. of the Carrancas region, Minas Gerais, Brazil. Darwiniana 40: 127-169.

Simões,A.O.,Endress,M.E,Van DerNiet,T., Kinoshita,L.S. \& Conti, E. 2006. Is Mandevilla (Apocynaceae, Mesechiteae) monophyletic? Evidence from five plastid DNA loci and morphology. Annals of the Missouri Botanical Garden 93: 565-591.

Thiers, B. 2008 (continuamente atualizado). Index Herbariorum: A global directory of public herbaria and associated staff. New York Botanical Garden's Virtual Herbarium. (http://sweetgum.nybg.org/ih (acesso em 25.01.2011)

Wyatt, R. \& Lipow, S.R. 2007. A new explanation for the evolution of pollinia and loss of carpel fusion in Asclepias and the Apocynaceae s.l.. Annals of the Missouri Botanical Garden 94: 474-484. 